\title{
Canola Responses to Drought, Heat, and Combined Stress: Shared and Specific Effects on Carbon Assimilation, Seed Yield, and Oil Composition
}

\author{
Raed Elferjani and Raju Soolanayakanahally* \\ Saskatoon Research and Development Centre, Agriculture and Agri-Food Canada, Saskatoon, SK, Canada
}

\section{OPEN ACCESS}

Edited by:

Alejandra A. Covarrubias, Universidad Nacional Autónoma de México, Mexico

Reviewed by:

Honglang Duan,

Nanchang Institute of Technology,

China

Jose Polania,

International Center for Tropical

Agriculture (CIAT), Colombia

*Correspondence:

Raju Soolanayakanahally

raju.soolanayakanahally@agr.gc.ca

Specialty section: This article was submitted to

Plant Abiotic Stress, a section of the journal Frontiers in Plant Science

Received: 21 March 2018

Accepted: 31 July 2018

Published: 30 August 2018

Citation: Elferjani $R$ and Soolanayakanahally $R$ (2018) Canola Responses to Drought,

Heat, and Combined Stress: Shared and Specific Effects on Carbon Assimilation, Seed Yield, and Oil Composition. Front. Plant Sci. 9:1224. doi: 10.3389/fp/s.2018.01224
Photosynthetic assimilation is remarkably altered by heat and drought, and this depends on the individual or combined occurrence of stressors and their respective intensities and durations. Abiotic stressors may also alter the nutritional quality and economic value of crops. In this controlled greenhouse study, we evaluated the response of Brassica napus L., from flowering to seed development, to two temperature and water treatments and a combination of these treatments. The diffusional limitations of stomatal conductance and mesophyll conductance on photosynthesis, as well as resource-use efficiency (particularly water and nitrogen), were assessed. In addition, the effects of stressors on the seed fatty acid content and composition and the total protein content were examined. The results showed that the reduction in the net photosynthetic assimilation rate was caused by combinations of heat and drought (heat + drought) treatments, by drought alone, and, to a lesser extent, by heat alone. The stomatal conductance decreased under drought and heat + drought treatments but not under heat. Conversely, the mesophyll conductance was reduced significantly in the plants exposed to heat and heat + drought but not in the plants exposed to drought alone. The carboxylation efficiency rate and the electron transport rate were reduced under the heat treatment. The seed yield was reduced by $85.3 \%$ under the heat treatment and, to a lesser extent, under the drought treatment (31\%). This emphasizes the devastating effects of hotter weather on seed formation and development. Seed oil content decreased by $52 \%$ in the plants exposed to heat, the protein content increased under all the stress treatments. Heat treatment had a more deleterious effect than drought on the seed oil composition, leading to enhanced levels of saturated fatty oils and, consequently, desaturation efficiency, a measure of oil frying ability. Overall, this study showed that except for the photosynthetic assimilation rate and stomatal conductance, heat, rather than drought, negatively affected the photosynthetic capacity, yield, and oil quality attributes when imposed during the flowering and silique-filling stages. This result highlights the necessity for a better understanding of heat tolerance mechanisms in crops to help to create germplasms that are adapted to rapid climate warming.

Keywords: photosynthesis, mesophyll conductance, water-use efficiency, nitrogen isotopic discrimination, saturated fatty acids, seed protein, Brassica napus $L$. 


\section{INTRODUCTION}

Alexander et al. (2006) and Yuan et al. (2016) noted the effects of anthropogenic climate change on fluctuating temperature and precipitation patterns in many biomes, including a direct effect on food security. A recent study reported that between 1964 and 2007, droughts and heat events resulted in losses of 1.82 and 1.19 billion metric tons, respectively, in cereal production (Lesk et al., 2016). Drought alone decreased the yield for wheat, rice, and maize by $\sim 13.7 \%$ during the same period. Both the frequency and the intensity of the drought episodes and heat waves have been increasing, and the consequences for crop yields are more disastrous than those from other climatic extremes, such as flooding, frost, or hail (Pachauri et al., 2014; Zscheischler et al., 2014). The climate projections for 2100 suggest a $50 \%$ increase in the number of areas affected by drought; thus, field crop yields might decrease by more than $50 \%$ if mitigation measures are not taken (Battisti and Naylor, 2009; Li et al., 2009).

One of the mechanisms by which plants sense drought is through their roots, when the soil water potential falls below a certain threshold, and abscisic acid (ABA)-driven hormonal signaling is transduced to their leaves, triggering stomatal closure to minimize water loss by transpiration (Flexas and Medrano, 2002). This response is concomitant with a decrease in the stomatal conductance $\left(g_{\mathrm{s}}\right)$ to carbon dioxide $\left(\mathrm{CO}_{2}\right)$ uptake and the production of carbohydrates to sustain growth and development. Heat waves, which are usually synchronous with drought, exacerbate this effect by accelerating soil drying and increasing the $\mathrm{H}_{2} \mathrm{O}$ vapor pressure deficit (VPD) in the air, further lowering $g_{\mathrm{s}}$ (Ohsumi et al., 2008; McDowell et al., 2011). By the end of this century, the average temperature might reach as high as $3.7^{\circ} \mathrm{C}$ based on HadGEM2-ES derived from CMIP5 Earth System Models (ESMs) outputs, and yields could decrease from 3.1 (soybean) to $7.4 \%$ (maize) for each degree (Celsius) increase in the global mean temperature (Zhao et al., 2017). In north temperate regions of Canada, the frequency of extreme hot temperatures exceeding $30^{\circ} \mathrm{C}$ is expected to increase by 2080-2100 (Kharin et al., 2007). Moreover, heat stress has a specific adverse effect on crop yields if it occurs during flowering and seed development (Saini et al., 1983; Jiang et al., 2015). Pollen development, pollination, ovule fertilization, and embryo development are sensitive to heat beyond a certain temperature threshold. This is particularly true for cool-climate crops, such as canola (Prasad et al., 2017; Rieu et al., 2017).

Water availability has significant implications for carbon assimilation, a necessary source of carbohydrates for plant growth. Insufficient water results in considerable yield losses (Flexas and Medrano, 2002). In a recent meta-analysis, Yan W. et al. (2016) reported that the diffusional limitations of $\mathrm{CO}_{2}$ by stomata could explain $55 \%$ of the carbon assimilation decline induced by drought. Moreover, it has been shown that limitations of $\mathrm{CO}_{2}$ diffusion also involve resistance through the pathway from the sub-stomatal cavity to the carboxylation site of ribulose-1,5-bisphosphate carboxylase/oxygenase (RuBisCO) in the chloroplast. This component is mesophyll conductance $\left(g_{\mathrm{m}}\right)$ and includes resistance by the intercellular spaces, cell walls, and membranes of the mesophyll cells and chloroplasts (Evans et al., 2009). Until recently, $g_{\mathrm{m}}$ was assumed to be steady and high enough to maintain a stable concentration of $\mathrm{CO}_{2}$ between the intercellular space $\left(C_{\mathrm{i}}\right)$ and the chloroplast $\left(C_{\mathrm{c}}\right)$ (Flexas et al., 2008). However, many studies have demonstrated that the $C_{\mathrm{c}}$ is significantly lower than the $C_{\mathrm{i}}$ and have concluded that $g_{\mathrm{m}}$ is minimal (Ethier and Livingston, 2004; Flexas et al., 2008). In addition, earlier studies reported $g_{\mathrm{m}}$ to be responsive to changes in environmental conditions, particularly heat and water deficits. This indicates a substantial limitation of photosynthetic carbon assimilation (Bernacchi et al., 2002; Warren, 2008). Under abiotic stress, the limited diffusion of $\mathrm{CO}_{2}$ by stomata or along the mesophyll pathway reduces the carboxylation rate $\left(V_{\mathrm{cmax}}\right)$ of RuBisCO. In addition, stressors affect the enzymes involved in the catalytic reactions in the Calvin-Benson cycle and, consequently, the carboxylation rate and the regeneration rates of Ribulose 1.5-bisphoshate, also reported as the electron transport rate $(J)$.

Studies on the effects of drought and heat on diffusional and biochemical limitations have reported quite different results depending on the plant species, the stress severity, and the duration and estimation methods. In addition, the specific effect of drought vs. heat on photosynthetic activity might be unclear, particularly for $\mathrm{C}_{3}$ crops, because of the co-occurrence of these conditions (Jagadish et al., 2011). Indeed, the respective actions of these conditions might target the different processes and structures involved in carbon assimilation to varying extents (Prasad et al., 2008). It is important, therefore, to characterize the specific effects of heat and drought on photosynthesis and yield to better understand the contribution of each of these stressors when they occur together. The identification of the traits in canola, particularly oil composition (i.e., the unsaturated vs. saturated fat ratio), affected by global warming has implications for phenotyping and breeding. In addition, these results can provide valuable information for managing irrigation when crops are exposed to heat waves and drought episodes.

The stable isotopic signatures of carbon $\left(\delta^{13} \mathrm{C}\right)$, oxygen $\left(\delta^{18} \mathrm{O}\right)$, and nitrogen $\left(\delta^{15} \mathrm{~N}\right)$ in plants are influenced by environmental parameters and can be reliable indicators of plants' responses to abiotic stress, particularly a water deficit (Farquhar et al., 1982; Handley et al., 1999). At the same time, a stable isotope composition could be intrinsic and could be significantly determined by the physiological characteristics of cultivars (Yousfi et al., 2012).

Brassica napus L. cropped mainly for edible oil and marketed as canola, has been a major oilseed crop since the 1970s. By 2014, production had increased to 68.9 million metric tons, and the harvested area had expanded to 33.7 million hectares (FAO, 2017). Canola oil, rich in polyunsaturated fatty acids, is considered a healthy ingredient, and it is the third most used oil in foods. The meal, a by-product of oil extraction, is used for animal feed because of its high protein content $(\sim 50 \%)$, and it is ranked second in global production after soybean meal. Like other major temperate field crops, B. napus is particularly vulnerable to environmental stress combinations, such as heat and drought (Champolivier and Merrien, 1996; Aksouh-Harradj et al., 2006). Genetic improvement measures to mitigate this problem have provided mid- and long-term results, 
but the need to increase crop yields is immediate because of the growing demands for food and feed. In addition to reducing yield, heat and drought can cause deterioration in the quality of the harvested parts of crops, thereby reducing their value and profitability. Although canola is harvested for the animal feed, lubricant, and paint industries, and, recently, the bioenergy industry, edible oil remains the main reason for canola cropping. Canola oil, with its high unsaturated/saturated fatty acid ratio, provides a health benefit that is superior to that of other oilseeds. However, this attribute is subject to significant changes, such as those reported for soybean, corn, and sunflower, because of changes in the lipid biosynthesis pathways as a result of environmental factors (Martínez-Rivas et al., 2003; Baud and Lepiniec, 2010).

This study addressed the comparative effects of heat, drought, and the combination of heat and drought (hereafter referred to as heat + drought) on the carbon assimilation pathways: the main drivers of seed yield and oil content in canola. The study also sought to better understand the specific effects of stressors on the fatty acids profile because such information is determinative for oil processing and maintaining the nutritional quality. To this end, the study aimed to answer the following questions: (i) What are the effects of drought, heat, and heat + drought on the diffusional limitations of $\mathrm{CO}_{2}$, carboxylation and electron transport capacities? (ii) To what extent do drought and heat affect oil content and composition? Three hypotheses were offered: (i) The drought effects would prevail over the heat effects in terms of the seed yield components (the weight of the seeds, the number of siliques, and the number of seeds/silique), and the effect of each stressor would depend on the other stressor (significant interaction effect). (ii) Drought would decrease the photosynthetic assimilation rate through the stomatal and mesophyll limitations of $\mathrm{CO}_{2}$ diffusion, but heat would alter the photosynthetic capacity. (iii) Drought, but not heat, would decrease the oil content, but the profile of fatty acids would be altered solely by heat.

\section{MATERIALS AND METHODS}

\section{Plant Growth Environment}

A Canadian elite Brassica napus L. cultivar (N99-508), widely used in Agriculture and Agri-Food Canada's (AAFC) breeding program, was chosen for the study. To simulate field conditions, topsoil was collected from agriculture fields close to Saskatoon, Canada $\left(52.15^{\circ} \mathrm{N}, 106.58^{\circ} \mathrm{W}\right)$, and mixed with $10 \%$ sand to provide better drainage. The soil type was chernozemic dark brown, and the texture was sandy loam with an average $\mathrm{pH}$ of 7.9 and 9, 23, and $295 \mathrm{ppm}$ of nitrogen, phosphorus and potassium nutrients, respectively. The details of the soil characteristics are summarized in Table S1. Eight 60 -liter plastic bins were filled with $50 \mathrm{~kg}$ of dry topsoil and slow-releasing fertilizer (Osmocote ${ }^{\circledR}$, Everris, U.S.A.) at a rate of $10.7 \mathrm{~g} / \mathrm{l}$ to avoid nutrient deficiency effects on plant growth and development. The bases and bottoms of the tubs were perforated for water drainage. In each bin, eight seeds were sown equidistantly and watered to field capacity.
The bins were divided equally between two adjacent greenhouses where the ambient day and night temperatures were $23 \pm 0.5^{\circ} \mathrm{C}$ and $18 \pm 0.5^{\circ} \mathrm{C}$, respectively. The relative humidity was $45-65 \%$. The photoperiod was set as a $16 \mathrm{~h}$ day and an $8 \mathrm{~h}$ night, and the minimum photosynthetic photon flux density (PPFD) was $400 \mu \mathrm{mol} \mathrm{m}^{-2} \mathrm{~s}^{-1}$ during the day. After a week of emergence, the plants were thinned, and the number was reduced to four per bin. The soil moisture was kept at field capacity by regular and light watering from emergence to bolting.

\section{Stress Treatments}

In the first greenhouse (GH-1), the daytime temperature was raised gradually and maintained at $29 \pm 0.5^{\circ} \mathrm{C}$ from the 38th day after sowing, and the night-time temperature was maintained at $18 \pm 0.5^{\circ} \mathrm{C}$. Two plastic bins (8 plants) were maintained at $90 \%$ water-holding capacity (heat, $\mathrm{H}$ ), and the remaining two plastic bins were allowed to reach $30 \%$ field capacity (heat + drought, $\mathrm{HD}$ ) and maintained at that level until silique/pod maturation. In the second greenhouse (GH-2), the daytime temperature was maintained at $23 \pm 0.5^{\circ} \mathrm{C}$, and the night-time temperature was maintained at $18 \pm 0.5^{\circ} \mathrm{C}$, with two bins ( 8 plants) at $90 \%$ water-holding capacity (well-watered, $\mathrm{WW}$ ) and the remaining bins at 30\% (drought, D). From bolting to final harvest, the soil moisture and the temperature regimes were monitored in both greenhouses using a WATERMARK soil moisture monitor (Model 900M, IRROMETER CA, USA) at $1 \mathrm{~h}$ intervals over the experiment. The sensors were set up in two randomly assigned tubs for each treatment. The water-holding capacity of the soil was determined as follows:

$$
W H C(\%)=\frac{W_{s a t}+72-W_{d r y}}{W_{d r y}} \times 100
$$

where $W_{\text {sat+72 }}$ is the weight after $72 \mathrm{~h}$ of drainage of $20 \mathrm{~L}$ of water-saturated soil, and $W_{\text {dry }}$ is the weight of $20 \mathrm{~L}$ of dry soil.

\section{Gas Exchange Measurements and Isotopic Discrimination}

The gas exchange measurements were performed using a LI-6400XT portable photosynthesis system equipped with a 6400-08 chamber attached to a 6400-02B LED light source (LICOR Inc., Lincoln, NE, U.S.A.) on days 9-11 after imposing the stress treatments. Measurements were made on the 4th fully developed leaf from the top $(N=32$; four stress treatments $x$ eight plants) between 8:30 and 11:30 a.m. The response of the net photosynthesis $\left(A, \mu \mathrm{mol} \mathrm{m} \mathrm{m}^{-2} \mathrm{~s}^{-1}\right)$ to the changing $C_{\mathrm{i}}$ was measured under saturated photosynthetic active radiation, PAR $=1,000 \mu \mathrm{mol} \mathrm{m} \mathrm{m}^{-2} \mathrm{~s}^{-1}$. The leaf was first exposed to a chamber $\mathrm{CO}_{2}$ concentration $\left(C_{\mathrm{a}}=400 \mu \mathrm{mol} \mathrm{CO} \mathrm{mol}^{-1}\right)$ using $\mathrm{CO}_{2}$ cartridges to reach a steady state. Next, the $C_{\mathrm{a}}$ was changed in the following order: $400,300,200,100,50,400,500,600,800$, 1,000 and $1,200 \mu \mathrm{mol} \mathrm{mol}^{-1}$. This was done while ensuring that the net photosynthetic assimilation rate $(A)$, water vapor, and $\mathrm{CO}_{2}$ fractions reached steady values at each step before moving to the next. During the measurement periods, the leaf chamber temperatures were kept at $23^{\circ} \mathrm{C}$ and $29^{\circ} \mathrm{C}$ depending on the greenhouse conditions: air flow at $500 \mu \mathrm{mol} \mathrm{s}^{-1}$, relative 
humidity at $55-65 \%$, and VPD at $1.2 \pm 0.1 \mathrm{KPa}$. The order of the measurements was randomized among the treatments and the days and along the measuring period. The $A\left(\mu \mathrm{mol} \mathrm{CO}_{2}\right.$ $\left.\mathrm{m}^{-2} \mathrm{~s}^{-1}\right)$ and the $g_{\mathrm{s}}\left(\mathrm{mol} \mathrm{CO} \mathrm{Cm}^{-2} \mathrm{~s}^{-1}\right)$ values were extracted from the $A-C_{\mathrm{i}}$ response measurements for $C_{\mathrm{a}}=400 \mu \mathrm{mol} \mathrm{CO}$ $\mathrm{mol}^{-1}$ (atmospheric ambient $\mathrm{CO}_{2}$ concentration). The intrinsic water-use efficiency $\left(\mathrm{WUE}_{\mathrm{i}}\right)$ was then deduced $\left(\mathrm{WUE}_{\mathrm{i}}=A / g_{\mathrm{s}}\right)$.

The maximum rate of RuBisCO carboxylation $\left(V_{\mathrm{cmax}}, \mu \mathrm{mol}\right.$ $\left.\mathrm{m}^{-2} \mathrm{~s}^{-1}\right)$, the rate of photochemical electron transport $(J, \mu \mathrm{mol}$ $\left.\mathrm{e}^{-} \mathrm{m}^{-2} \mathrm{~s}^{-1}\right)$, and the rate of $\mathrm{CO}_{2}$ diffusion from the $C_{\mathrm{i}}$ to the $C_{\mathrm{c}}$ carboxylation site or $g_{\mathrm{m}}\left(g_{\mathrm{m}}, \mathrm{mol} \mathrm{m}^{-2} \mathrm{~s}^{-1}\right)$ were estimated by $A-C_{\mathrm{i}}$ curve fitting, according to Ethier and Livingston (2004) and Ethier et al. (2006), with the biochemical model of $\mathrm{C}_{3}$ photosynthesis developed by Farquhar et al. (1980).

The final rate, $A$, was:

$$
A=\min (A c, A j)
$$

The RuBisCO-limited rate of $\mathrm{CO}_{2}$ assimilation $\left(A_{c}\right)$ was given by:

$$
A_{c}=\frac{\left(C_{i}-\Gamma^{*}\right) V_{c \max }}{C_{i}+K_{c}\left(1+O / K_{o}\right)}-R_{d}
$$

where $V_{c \operatorname{cmax}}$ is the maximum rate of carboxylation, $C_{c}$ is the chloroplast concentration of $\mathrm{CO}_{2}, C_{\mathrm{i}}$ is the intercellular concentration of $\mathrm{CO}_{2}, \Gamma^{*}$ is the $\mathrm{CO}_{2}$ compensation point, and $K_{\mathrm{c}}$ and $K_{\mathrm{o}}$, are the Michaelis-Menten constants of RuBisCO for $\mathrm{CO}_{2}$ and $\mathrm{O}_{2}$, respectively.

The RuBP-limited rate of $\mathrm{CO}_{2}$ assimilation $\left(A_{j}\right)$ was given by:

$$
A_{j}=\frac{\left(C_{i}-\Gamma^{*}\right) J / 4}{C_{i}+2 \Gamma^{*}}-R_{d}
$$

where $J$ is the rate of electron transport. The rate of electron transport was given by:

$$
J=\frac{4\left(A_{j}+R_{d}\right)\left(C_{i}-\frac{A_{j}}{g_{i}}+2 \Gamma^{*}\right)}{\left(C_{i}-\frac{A_{j}}{g_{i}}-\Gamma^{*}\right)}
$$

The $g_{\mathrm{m}}$ was calculated from:

$$
\frac{1}{g_{m}}=\frac{1}{g_{i}}+\frac{1}{K_{c}}
$$

where

$$
g_{i}=\frac{A}{C_{i}-C_{c}}
$$

and $K_{\mathrm{c}}$ is the carboxylation efficiency (the initial slope of the $A-C_{\mathrm{c}}$ curve)

$$
K_{c}=\frac{d A}{d C_{c}}
$$

Once the gas exchange measurements were recorded from the very same 4 th leaf, 10 leaf punches $(5 \mathrm{~mm}$ diameter $)$ were collected, using a single-hole punch, on either side of the midrib toward the stable isotopic composition of carbon $\left(\delta^{13} \mathrm{C}\right)$, nitrogen $\left(\delta^{15} \mathrm{~N}\right)$, and oxygen $\left(\delta^{18} \mathrm{O}\right)$, as well as the carbon:nitrogen $(\mathrm{C}: \mathrm{N})$ ratio. Later, the leaf punches were oven-dried at $60^{\circ} \mathrm{C}$ for $72 \mathrm{~h}$ at constant mass. Four (4) of the leaf discs were weighed and individually packed in tin $\left(\delta^{13} \mathrm{C}\right.$ and $\left.\delta^{15} \mathrm{~N}\right)$ and silver $\left(\delta^{18} \mathrm{O}\right)$ capsules. They were then sent to the University of California at Davis Stable Isotope Facility to be combusted and analyzed by an online continuous flow dual analyzer coupled to an isotope ratio mass spectrometer (Europa Scientific Integra, Cheshire, England, UK). The values for leaf discrimination against the heavy isotope $\Delta^{13} \mathrm{C}$ were calculated, following Farquhar et al. (1989), as:

$$
\Delta^{13} C=\frac{\delta^{13} C_{a}-\delta^{13} C_{\text {leaf }}}{1+\delta^{13} C_{\text {leaf }}}
$$

where $\delta^{13} \mathrm{C}_{\mathrm{a}}$ and $\delta^{13} \mathrm{C}_{\text {leaf }}$ are, respectively, the carbon isotope composition of the ambient air $(-8.3 \%)$ and the leaf sample with, as reference, the Vienna PeeDee Belemnite (VPDB) carbonate standard, according to the following formula:

$$
\delta^{13} C=\frac{\left({ }^{13} C /{ }^{12} C\right)_{\text {sample }}-\left({ }^{13} C /{ }^{12} C\right)_{V P D B}}{\left({ }^{13} C /{ }^{12} C\right)_{V P D B} \cdot 1,000}
$$

where $\left({ }^{13} \mathrm{C} /{ }^{12} \mathrm{C}\right)_{\text {sample }}$ and $\left({ }^{13} \mathrm{C} /{ }^{12} \mathrm{C}\right)_{\mathrm{VPDB}}$ are the ratios of ${ }^{13} \mathrm{C}$ and ${ }^{12} \mathrm{C}$ in the sample and the VPDB, respectively.

In the same way, $\delta^{15} \mathrm{~N}$ and $\delta^{18} \mathrm{O}$ were calculated as:

$$
\begin{array}{r}
\delta^{15} N=\frac{\left({ }^{15} N /{ }^{14} N\right)_{\text {sample }}-\left({ }^{15} N /{ }^{14} N\right)_{\text {AIR }}}{\left({ }^{15} \mathrm{~N} /{ }^{14} N\right)_{\text {AIR }} \cdot 1,000} \\
\delta^{18} O=\frac{\left({ }^{18} O /{ }^{16} O\right)_{\text {sample }}-\left({ }^{18} O /{ }^{16} O\right)_{\text {VSMOW }}}{\left({ }^{18} \mathrm{O} /{ }^{16} O\right)_{\text {VSMOW }} \cdot 1,000}
\end{array}
$$

The Vienna standard mean ocean water (VSMOW) and atmospheric nitrogen were the standards used to calculate the $\delta^{18} \mathrm{O}$ and $\delta^{15} \mathrm{~N}$, respectively. All of the isotopic values were expressed in per mil (\%), and the error of the repeated measurements did not exceed $0.1 \%$.

\section{Abscisic Acid Content}

A fully expanded leaf (5th leaf from the top) was sampled and immediately packed in Eppendorf tubes and frozen in liquid nitrogen before being stored in a $-80^{\circ} \mathrm{C}$ freezer until processed for analysis. The ABA content was determined as described in Yan D. et al. (2016). The samples were centrifuged to remove debris, and the pellet was washed twice. The supernatant was evaporated in a SpeedVac, reconstituted in $1 \mathrm{ml}$ of $1 \%(\mathrm{v} / \mathrm{v})$ acetic acid, and purified by solid phase extraction using Oasis HLB, MCX, and WAX cartridge columns (Waters Limited, Mississauga ON, Canada). The solvent was removed under vacuum and subjected to the LC-ESI-MS/MS analysis (Agilent 6410 TripleQuad LC/MS system). A Liquid Chromatography (Agilent 1200 series) equipped with a $50 \times 2.1 \mathrm{~mm}, 1.8 \mu \mathrm{m}$ Zorbax SB-Phenyl column (Agilent) was used with a binary solvent system comprising $0.01 \%(\mathrm{v} / \mathrm{v})$ acetic acid in water 
(Solvent A) and $0.05 \%(\mathrm{v} / \mathrm{v})$ acetic acid in acetonitrile (Solvent B). The separations were performed using a gradient of increasing acetonitrile content with a flow rate of $0.2 \mathrm{ml} \mathrm{min}^{-1}$. The gradient was increased linearly from 3 to $50 \% \mathrm{~B}$ over $15 \mathrm{~min}$. The retention time for the ABA was $14.0 \mathrm{~min}$.

\section{Growth}

The normalized difference vegetation index (NDVI) was measured using a GreenSeeker handheld crop sensor (Trimble, Westminster CO, USA). The sensor was held $80 \mathrm{~cm}$ above the plant canopy, as recommended by the manufacturer. The measurements were taken between 9 and $11 \mathrm{a} . \mathrm{m}$. just before flowering started. Plant height was measured at physiological maturity.

\section{Harvest}

Upon reaching physiological maturity, the siliques were harvested, counted, and stored in a dryer at $23^{\circ} \mathrm{C}$ for $4-5$ days before threshing. The seeds were then collected, counted, and weighed. Later, the seeds were sent to AAFC's oil chemistry lab in Saskatoon for oil and protein analyses. To qualify the effects of the combined vs. the single stressors on the yield traits and the photosynthetic $A$, the effect weights of drought $(\mathrm{D})$, heat $(\mathrm{H})$, and heat + drought (HD), compared to the well-watered (WW) treatment were calculated using the following formula:

$$
T_{e}=\frac{X_{t}-\bar{X}_{W W}}{\bar{X}_{W W}}
$$

where $T_{e}$ is the treatment effect weight, $X_{t}$ is the trait " $X$ " value for the treatment $T$, and $\bar{X}_{W W}$ is the corresponding mean value for the well-watered plants. The heat + drought effect weight obtained with the above formula $\left(\mathrm{HD}_{\mathrm{e}}\right)$ was compared to the calculated heat + drought effect $\left(H D_{\text {calc }}\right)$ using the following formula:

$$
H D_{\text {calc }}=\bar{H}_{e}+\bar{D}_{e}-\bar{H}_{e} \times \bar{D}_{e}
$$

where $\bar{H}_{e}$ and $\bar{D}_{e}$ are the means of the heat and drought effect weights, respectively (Darling et al., 2010; Bansal et al., 2013).

\section{Fatty Acid and Protein Content of Seeds}

The seeds were pooled from each stress treatment and further divided into three sub-samples for analyses of the total oil content, fatty acid composition, and total protein content. The seed oil fatty acyl composition was analyzed using gas chromatography (GC) following the preparation of the fatty acid methyl esters by base-catalyzed methanolysis (Thies, 1971) and according to the protocol detailed in Heydarian et al. (2016). The individual fatty acids were reported as a percentage of the total fatty acid methyl esters by mass. The total oil content was calculated as the sum of the content of the individual triglycerides. The seed protein content was determined by the American Oil Chemists' Society's generic combustion method for crude protein (Official Method Ba 4e-93). Combustion at a high temperature in pure oxygen frees nitrogen, which is measured by thermal conductivity detection and then converted to the equivalent protein by an appropriate numerical factor (AOAC,
2003). A LECO FP-528 protein analyzer was used, and the results were reported as a percentage, $N \times 6.25$, calculated on a wholeseed dry matter (zero moisture) basis. Subsequently, the $\omega-3$ desaturation efficiency (DE) and the $\omega-6 \mathrm{DE}$ were deduced from the profile of the fatty acids and calculated according to Menard et al. (2017):

$$
\begin{aligned}
& \omega-3 D E=\frac{18: 3}{18: 2+18: 3} \\
& \omega-6 D E=\frac{18: 2+18: 3}{18: 1+18: 2+18: 3}
\end{aligned}
$$

\section{Statistical Analyses}

A two-way analysis of variance (ANOVA) was used to test the effects of the ambient temperature, the water status, and the interaction between them on the measured traits. The means were compared using Tukey's honest significant difference (HSD) at a $p<0.05$ significance level. The coefficients and the $p$-values of the correlations were calculated using Pearson's correlation coefficient. All of the statistical analyses were performed with $\mathrm{R}$ software version 3.2.2 (R Core Team, 2015).

\section{RESULTS}

Heat had a significant effect on the photosynthetic-related variables $\left(A, V_{\mathrm{cmax}}, J\right.$, and $\left.g_{\mathrm{m}}\right)$ but not on $g_{\mathrm{s}}, \mathrm{WUE}_{\mathrm{i}}$ and $\Delta^{13} \mathrm{C}$ (Table 1). Heat also affected the growth attributes (plant height and NDVI) and all of the measured yield and oil quality attributes. In addition, the $\delta^{15} \mathrm{~N}$ levels were significantly affected by heat alone. The available soil moisture status (drought) had a significant effect on all of the photosynthesis variables except $g_{\mathrm{m}}$, the growth and yield attributes, and the ABA and seed protein content (Table 1). The heat + drought interaction did not significantly affect the measured variables except for the $\Delta^{13} \mathrm{C}$ and the oil content (Table 1). It had a marginally significant effect $(p=0.06)$ on the NDVI and the seed weight.

\section{Photosynthetic Carbon Fixation Capacity and Growth}

Although heat and drought significantly reduced the net photosynthetic $A$, the heat + drought treatment had the greatest effect: the $A$ was $\sim 55 \%$ less than the $A$ for the well-watered plants (Table 2). In addition, the drought treatment had a greater effect on the $A\left(19.4 \mu \mathrm{mol} \mathrm{CO} \mathrm{Cm}^{-2} \mathrm{~s}^{-1}\right)$ than did the heat treatment $\left(22.45 \mu \mathrm{mol} \mathrm{CO} \mathrm{m}^{-2} \mathrm{~s}^{-1}\right)$; however, the well-watered plants maintained the highest photosynthetic carbon fixation capacity $\left(26.74 \mu \mathrm{mol} \mathrm{CO} 2 \mathrm{~m}^{-2} \mathrm{~s}^{-1}\right.$; see Figure 1A). Compared to the $g_{\mathrm{s}}$ under the well-watered treatment $\left(0.52 \mathrm{~mol} \mathrm{CO}_{2} \mathrm{~m}^{-2}\right.$ $\mathrm{s}^{-1}$ ), the $g_{\mathrm{s}}$ for the plants exposed to the heat treatment did not change significantly $\left(0.48 \mathrm{~mol} \mathrm{CO}_{2} \mathrm{~m}^{-2} \mathrm{~s}^{-1}\right)$; however, it dropped sharply in the plants exposed to drought $\left(0.14 \mathrm{~mol} \mathrm{CO}_{2}\right.$ $\mathrm{m}^{-2} \mathrm{~s}^{-1}$; see Figure 1B). The $\mathrm{WUE}_{\mathrm{i}}$ was similar between the treatments (well-watered and heat) when water was supplied, averaging $30.75 \mu \mathrm{mol} \mathrm{CO}_{2} \mathrm{~mol}^{-1} \mathrm{H}_{2} \mathrm{O}$ (Figure 1C). In contrast, the $\mathrm{WUE}_{\mathrm{i}}$ rose significantly, by $\sim 173 \%$, in the plants subjected to a water deficit (drought and heat + drought treatments). The leaf $\mathrm{ABA}$ content, being low under the well-watered and heat 


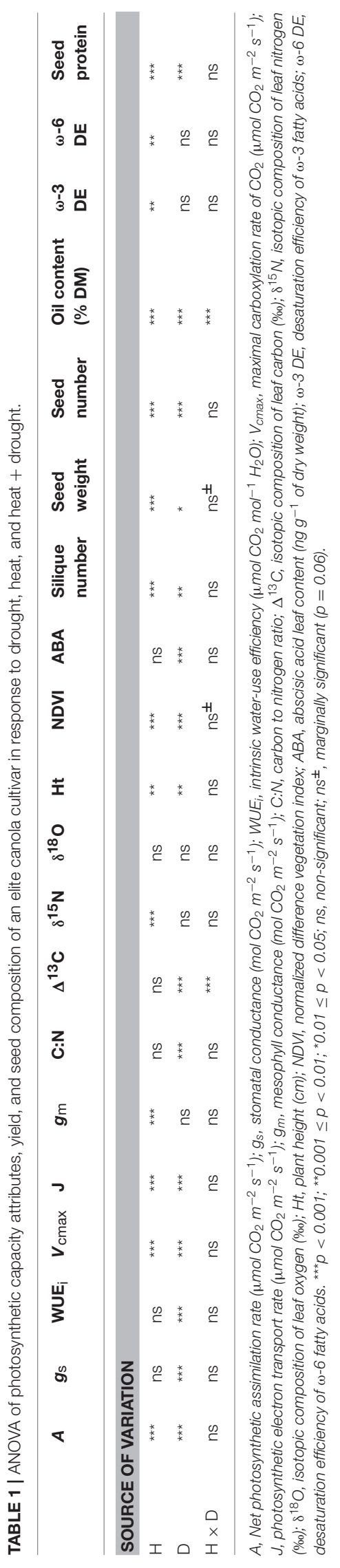

TABLE 2 | Effect weight of net photosynthetic assimilation rate $(A)$ and yield traits as the deviation of the trait value under single and combined stressors on the value under the control conditions (well-watered plants).

\begin{tabular}{llllll}
\hline & $\mathbf{D}_{\mathbf{e}}$ & $\mathbf{H}_{\mathbf{e}}$ & $\mathbf{H D}_{\mathbf{e}}$ & $\mathbf{H}+\mathbf{D}_{\text {calc }}$ & $\begin{array}{l}\text { Result of combined } \\
\text { stressors }\end{array}$ \\
\hline Silique number & 0.49 & 0.59 & 0.82 & 0.80 & Cumulative \\
Seed weight & 0.31 & 0.85 & 0.89 & 0.90 & Heat dominant \\
Seeds number & 0.36 & 0.70 & 0.85 & 0.79 & Cumulative \\
Oil content (\%DM) & Null & 0.53 & 0.19 & 0.53 & Antagonistic
\end{tabular}

$D_{e}$, effect weight of drought treatment (vs. well-watered plants); $H_{e}$, effect weight of drought treatment; $H D_{e}$, effect weight of heat and drought combination; $H+D_{\text {calc }}$, calculated effect weight of heat and drought combination.

treatments (219.1 and $198.1 \mathrm{ng} \mathrm{g}^{-1} \mathrm{DM}$, respectively), mirrored the WUE $\mathrm{W}_{\mathrm{i}}$ patterns (Figure 2) and increased noticeably when the plants were exposed to a soil water deficit under drought and heat + drought (2,195 and 2,209 $\mathrm{ng} \mathrm{g}^{-1} \mathrm{DM}$, respectively).

Unlike the result for the $g_{\mathrm{s}}$, the $g_{\mathrm{m}}$ decreased significantly on exposure to heat $(25 \%)$ but did not change under the drought treatment $\left(0.13 \mathrm{~mol} \mathrm{CO}_{2} \mathrm{~m}^{-2} \mathrm{~s}^{-1}\right.$; see Figure 3A). The heat + drought combination decreased $g_{\mathrm{s}}$ and $g_{\mathrm{m}}$ significantly; however, the effect of the single stressors was not significantly greater. Compared to those for the well-watered plants, the maximal $V_{\text {cmax }}$ and $J$ were reduced under the heat + drought treatment and, to a lesser extent, under the heat but not the drought treatment, following a similar trend as that for $g_{\mathrm{m}}$ (Figures 3B,C). The $V_{\text {cmax }}$ was $84.4 \mu \mathrm{mol} \mathrm{m}^{-2} \mathrm{~s}^{-1}$ under the well-watered treatment and dropped to 63.2 and $43.9 \mu \mathrm{mol}$ $\mathrm{m}^{-2} \mathrm{~s}^{-1}$ in the plants exposed to the heat and heat + drought treatments, respectively (Figure 3B). The $J$ followed a similar pattern as that for the $V_{\text {cmax }}$, going from $178.2 \mu \mathrm{mol} \mathrm{\textrm {e } ^ { - }}$ $\mathrm{m}^{-2} \mathrm{~s}^{-1}$ for the well-watered plants to 133.2 and $95.4 \mu \mathrm{mol}$ $\mathrm{e}^{-} \mathrm{m}^{-2} \mathrm{~s}^{-1}$ for the plants exposed to the heat and heat + drought treatments, respectively (Figure 3C). Plant height averaged $145.8 \mathrm{~cm}$ under the control conditions and decreased under all the stress treatments. Height was the most affected by the heat + drought treatment, decreasing by $35.8 \%$ as compared to the well-watered plants (data not shown). The NDVI was 0.76 for the well-watered plants. It decreased under the drought and heat + drought treatments to 0.69 and 0.60 , respectively. However, the NDVI was not affected by the heat treatment.

\section{Resource-Use Efficiencies}

The isotopic composition of the leaf carbon, $\Delta^{13} \mathrm{C}(\%)$, was sensitive to the stress treatments, and discrimination reduced on exposure to heat + drought and drought (Figure 4A). The observed pattern in the $\Delta^{13} \mathrm{C}$ was similar to that in the $g_{\mathrm{s}}$, where a significant correlation was found between $g_{\mathrm{s}}$ and the $\Delta^{13} \mathrm{C}\left(R^{2}=0.50, p<0.01\right.$; see Figure 5A $)$, but no correlation was found between the $g_{\mathrm{m}}$ and the $\Delta^{13} \mathrm{C}\left(R^{2}\right.$ $=0.03, p=0.36$; see Figure $5 \mathbf{B})$. This result suggests that carbon discrimination is driven mainly by stomatal closure. The treatment differences in the $\delta^{15} \mathrm{~N}$ were more noticeable, and 

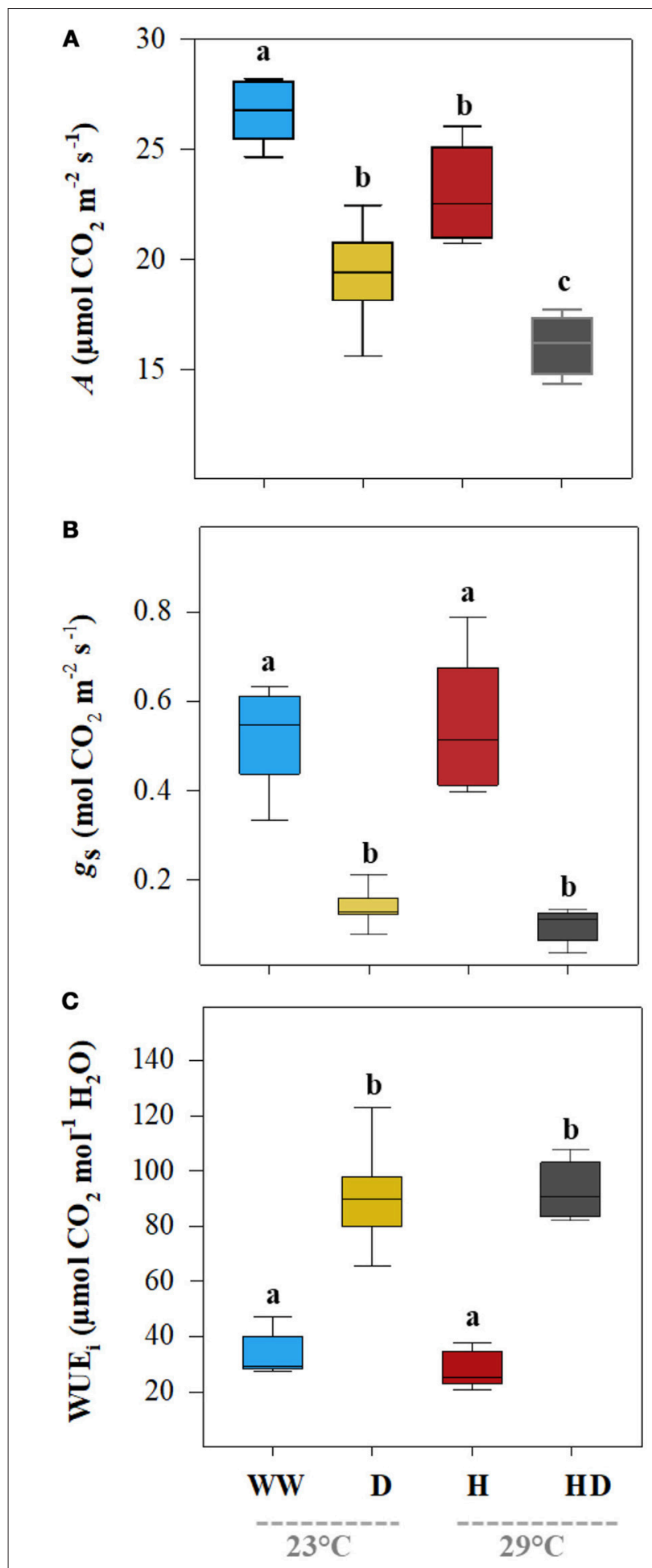

FIGURE 1 | The leaf net photosynthetic assimilation rate $(A, \mathbf{A})$, stomatal conductance of $\mathrm{CO}_{2}\left(g_{\mathrm{s}}, \mathbf{B}\right)$, and intrinsic water use efficiency $\left(\mathrm{WUE}_{i}=\mathrm{A} / \mathrm{g}_{\mathrm{s}}\right.$, C) of the plants grown under the well-watered (WW), drought $(D)$, heat $(H)$, and heat + drought $(\mathrm{HD})$ treatments. The statistically significant differences among the treatments are labeled with different letters at $p<0.05$ (Tukey's HSD). The box ends indicate the upper (3rd) to lower (1st) quartiles of the value ranges, and the whiskers indicate the highest and lowest observations. The horizontal line inside the box marks the median for the observations.

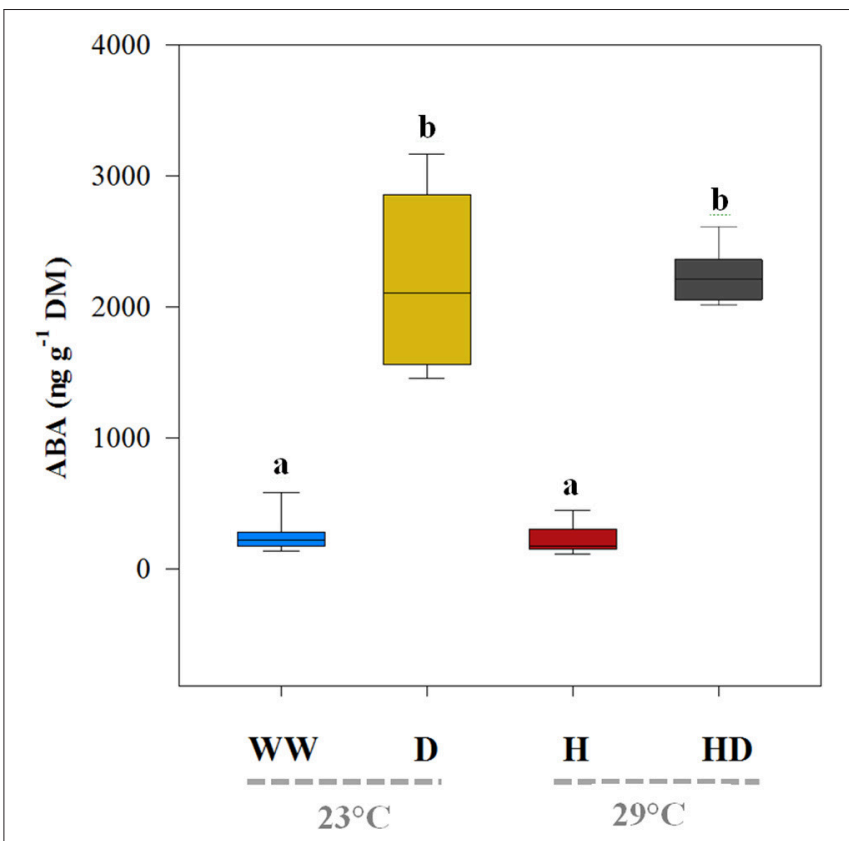

FIGURE 2 | The leaf abscisic acid content (ABA) of the plants exposed to the well-watered (WW), drought $(D)$, heat $(H)$, and heat + drought $(H D)$ treatments. The statistically significant differences among the treatments are labeled with different letters at $p<0.05$ (Tukey's HSD). The box ends indicate the upper (3rd) to lower (1st) quartiles of the value ranges, and the whiskers indicate the highest and lowest observations. The horizontal line inside the box marks the median for the observations.

the values ranged from $0.59 \%$ (well-watered) to $2.72 \%$ (heat + drought; see Figure 4B). The $\delta^{15} \mathrm{~N}$ plotted against the $g_{\mathrm{m}}$ showed a significant negative correlation $\left(R^{2}=0.34, p<0.01\right.$; see Figure 5D), while no significant correlation was found between $\delta^{15} \mathrm{~N}$ and $g_{s}$ (Figure 5C). Similarly, both the $V_{\mathrm{cmax}}$ and the $J$ were negatively correlated with the $\delta^{15} \mathrm{~N}\left(R^{2}=0.32\right.$ and $0.27, p$ $<0.01$, respectively; see Figure $\mathbf{S 1}$ ). The observed $\delta^{18} \mathrm{O}$ was not significantly different for the treatments, and the average value was $17.82 \%$ (Table 1 ).

\section{Seed Yield and Total Oil and Protein Content}

The number of siliques decreased noticeably by exposure to heat + drought $(76 \%)$ and less by heat $(43 \%)$ compared to the well-watered plants, which had 178 siliques/plant on average (Figure 6). The plants exposed to drought were less affected, with 125 siliques per plant. The seed yield was highest for the well-watered plants ( $6.46 \mathrm{~g} / \mathrm{plant})$. It diminished by $85 \%$ and $89 \%$ for the plants exposed to heat and heat + drought, respectively, and by $31 \%$ for the plants subjected to drought (Table 2).

On average, the oil content (\% of seed dry matter) of the plants under the heat treatment was particularly low $(17.2 \%)$ compared to $36.1 \%$ in the seeds of the well-watered plants (Figure 7A). The oil content (35.7\%) was not significantly affected by drought, but when heat and drought were combined, it dropped to $29.2 \%$. 

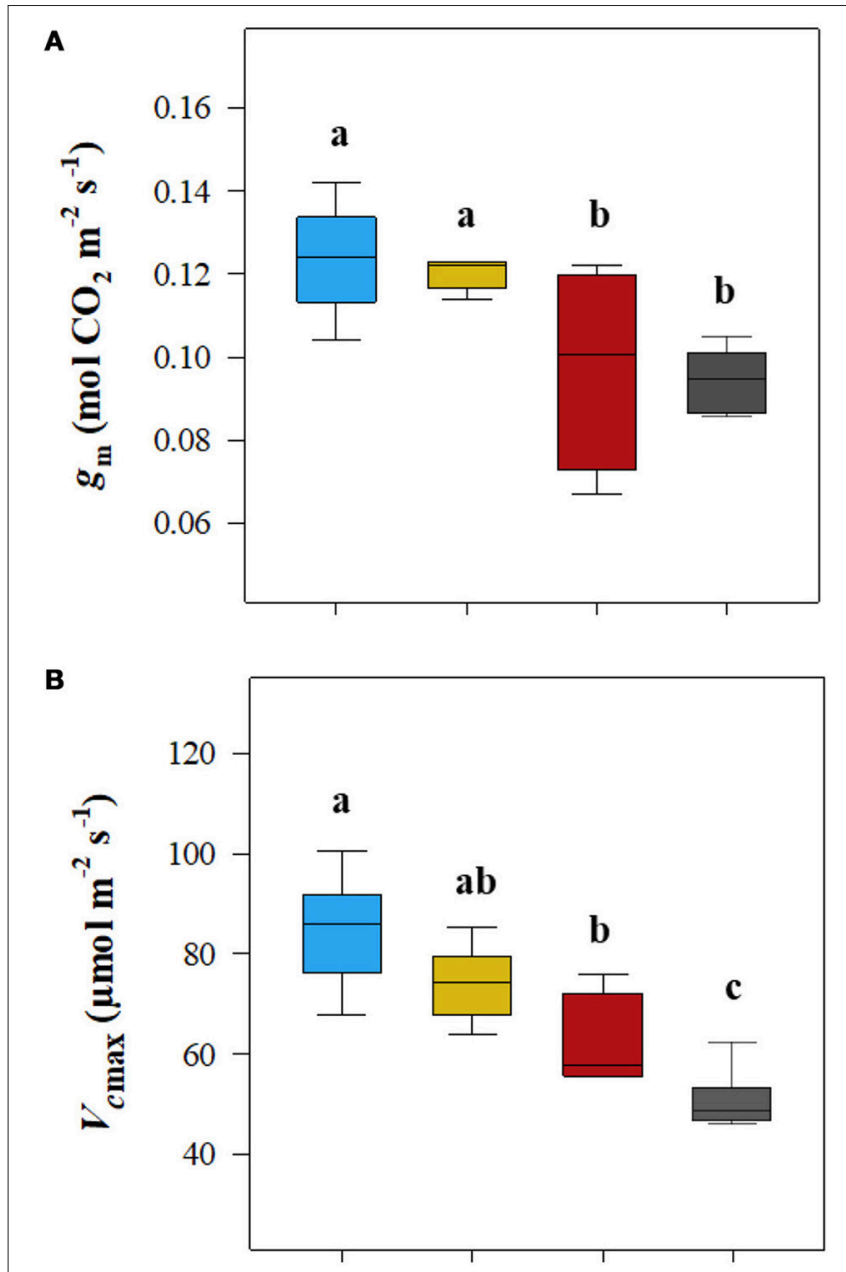

C

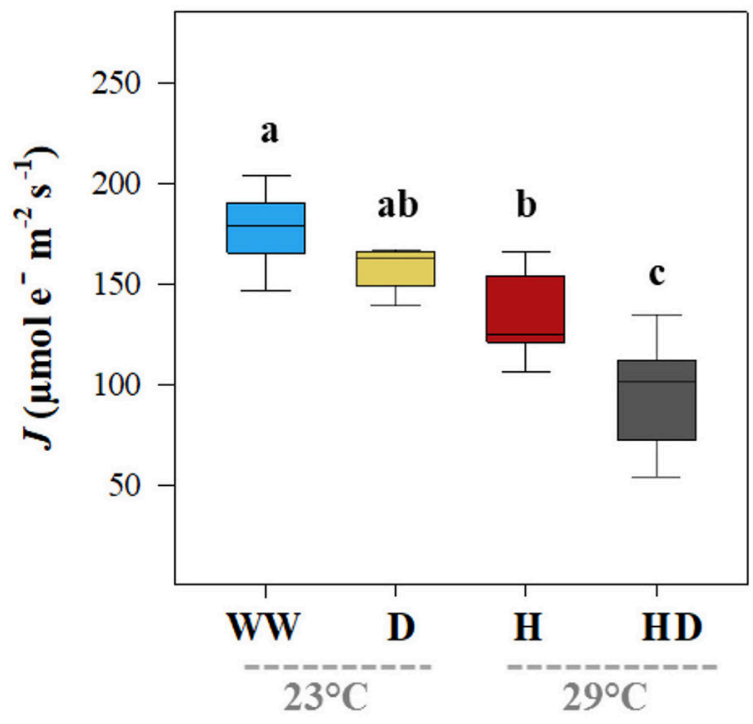

FIGURE 3 | The leaf mesophyll conductance for $\mathrm{CO}_{2}\left(g_{\mathrm{m}}, \mathbf{A}\right)$, the maximum carboxylation rate of ribulose-1,5-bisphosphate carboxylase/oxygenase $\left(V c_{\max }, \mathbf{B}\right)$, and the photosynthetic rate of the electron transport $(J, \mathbf{C})$ for the plants exposed to the well-watered (WW), drought $(D)$, heat $(H)$, and heat +

(Continued)
FIGURE 3 | drought (HD) treatments. The statistically significant differences among the treatments are labeled with different letters at $p<0.05$ (Tukey's HSD). The box ends indicate the upper (3rd) to lower (1st) quartiles of the value ranges, and the whiskers indicate the highest and lowest observations. The horizontal line inside the box marks the median for the observations.
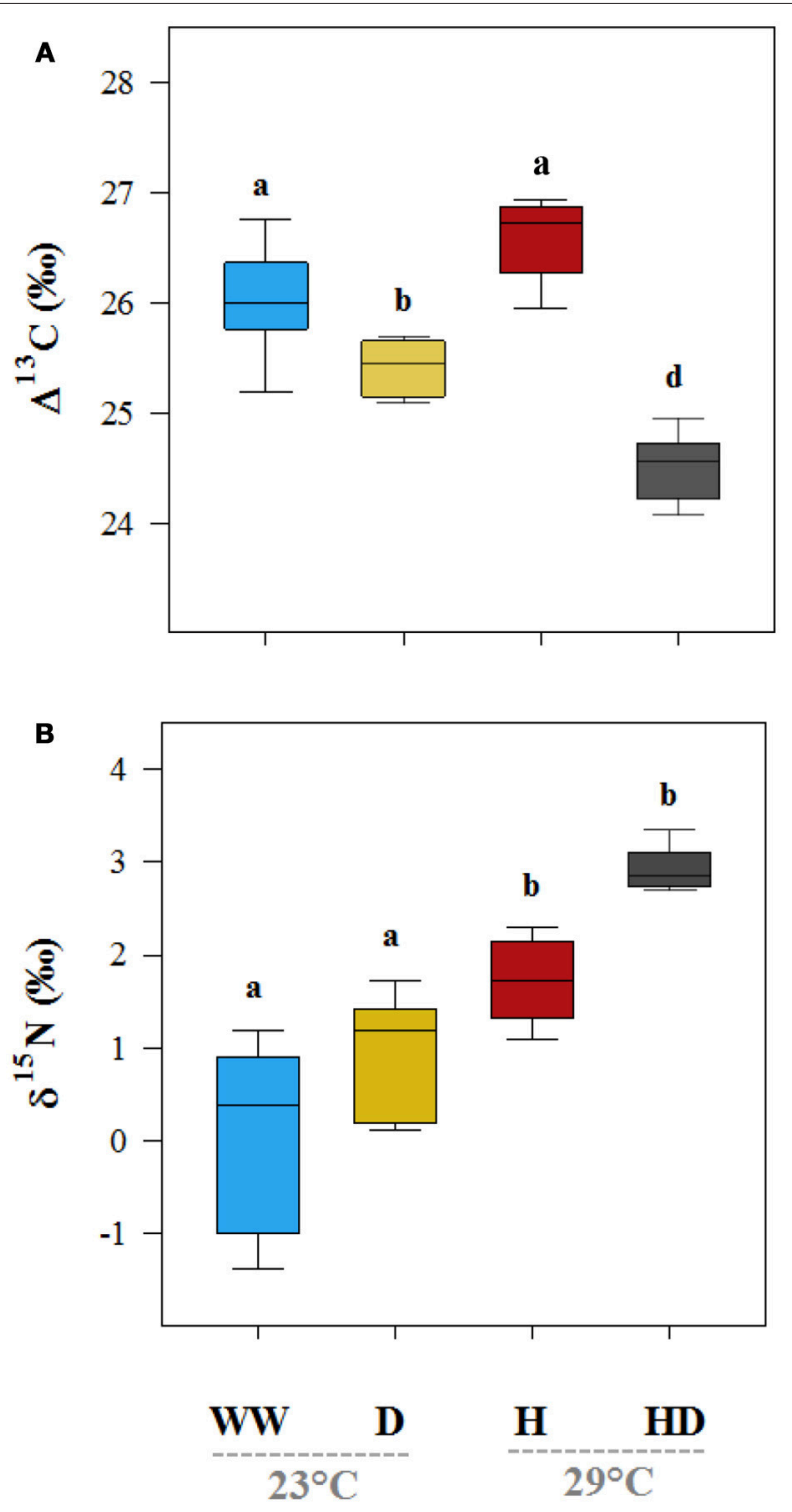

FIGURE 4 | The effects of the well-watered (WW), drought $(D)$, heat $(H)$, and heat + drought $(H D)$ treatments on leaf carbon $\left(\Delta^{13} \mathrm{C}, \mathbf{A}\right)$ and the nitrogen $\left(\delta^{15} \mathrm{~N}, \mathbf{B}\right)$ isotopic composition. Different letters denote significantly different treatments at $p<0.05$ (Tukey's HSD). The box ends indicate the upper (3rd) to lower (1st) quartiles of the value ranges, and the whiskers indicate the highest and lowest observations. The horizontal line inside the box marks the median for the observations.

The total protein content (\% dry matter) was 30\% in the seeds of the well-watered plants. It increased under all of the stress treatments (drought $32.8 \%$, heat $37.2 \%$, and heat + drought $39 \%$; see Figure 7B). The DE of the $\omega-6$ fatty acids increased 
significantly as compared to the $\mathrm{DE}$ in the well-watered plants (17.3) when the plants were exposed to the heat treatment (25.5), but it did not change significantly when the plants were exposed to the drought and the heat + drought treatments (Figure 8A). The drought and heat + drought stress treatments increased the unsaturated fatty acid fraction. The heat treatment increased the saturated fatty acid fraction, but the drought treatment lowered it (Figure S2). The heat application resulted in a decrease in the oleic acid (18:1) content and an increase in the linoleic acid (18:2; see Figure S2). In contrast, the plants exposed to heat and heat + drought had a lower $\omega-3 \mathrm{DE}$ (0.24 on average) than the well-watered plants $(0.33$; see Figure $\mathbf{8 B})$ as the $\alpha$-Linolenic acid (18:3) content decreased and the linoleic (18:2) increased (Figure S2).

\section{Relationships Among Photosynthesis, Resource-Use Efficiency, and Yield}

The biochemical limitations of photosynthesis $\left(V_{\mathrm{cmax}}, J\right.$, and $g_{\mathrm{m}}$ ) and yield attributes (silique number, seed number, and seed weight) were negatively correlated with the $\delta^{15} \mathrm{~N}$, but a positive correlation was observed between the $\delta^{15} \mathrm{~N}$ and the seed protein content (Figure 9). As for the seed composition, the oil content was positively correlated with the physiological variables $(A$, $V_{c \max }, J$, and $\left.g_{\mathrm{m}}\right)$ and with the $\omega-3 \mathrm{DE}\left(R^{2}=0.63\right)$ but negatively related to the $\omega-6 \mathrm{DE}\left(R^{2}=0.88\right)$.

\section{DISCUSSION}

The results of this work emphasizes an exacerbating effect of combined heat and drought on spring canola growth and yield, compared to single applications of stressors as reported for other crops (Nankishore and Farrell, 2016; Mahrookashani et al., 2017; Sehgal et al., 2017). In addition, we noticed a prevailing effect of heat over drought on photosynthetic capacity, yield and seed composition traits, most likely due to the deleterious effect of heat on the enzymes involved in carbon assimilation and metabolism. However, drought specifically affected stomatal conductance of $\mathrm{CO}_{2}$ and related traits (ABA content, $\Delta{ }^{13} \mathrm{C}$ and net assimilation rate).

\section{Response of $\mathrm{CO}_{2}$ Diffusion and Photosynthetic Capacity to Heat and Drought}

Photosynthetic activity is sensitive to both drought and heat, particularly for $\mathrm{C}_{3}$ metabolic pathway crops, and the degree of tolerance to stressors is determinant for their survival (Feller and Vaseva, 2014). The rapid acclimation of photosynthesis to abiotic stressors has been reported for many species, particularly in response to drought and, to a lesser extent, heat. Acclimation, also termed phenotypic plasticity, consists of adjustments of physiological traits, resulting in a limited decline in growth performance (Sadras et al., 2009).

In this experiment, $g_{\mathrm{s}}$ was affected when plants were subjected to a water deficit (drought and heat + drought treatments). Under the drought conditions and the optimal temperature $\left(23^{\circ} \mathrm{C}\right)$, the $\mathrm{ABA}$ leaf content increased dramatically leading to stomatal closure. This suggests that the ABA signaling pathway triggered stomatal closure to reduce the loss of tissue turgor (Wilkinson and Davies, 2010; Pantin et al., 2013). However, keeping the stomata open at a high temperature and in increased leaf-to-air VPD conditions ensures leaf transpirational cooling, but this is conditional to soil moisture availability in the root zone (Crawford et al., 2012). The findings of this study are consistent with those of previous studies. High $g_{\mathrm{s}}$ was seen in plants subjected to the heat $\left(29^{\circ} \mathrm{C}\right)$ and the well-watered $\left(23^{\circ} \mathrm{C}\right)$ conditions, and low $g_{\mathrm{s}}$ was observed under the drought and the heat + drought conditions. Overall, the response of the canola plants seemed to be a "conservational" strategy driven by water economy via stomatal closing rather than leaf cooling. This resulted in greater water-use efficiency but a lower $A$.

The range and the response of $g_{\mathrm{m}}$ to temperature were reported to be markedly different among species (von Caemmerer and Evans, 2015). The $g_{\mathrm{m}}$ increased linearly in response to a temperature gradient ranging from 15 to $40^{\circ} \mathrm{C}$ for Gossypium, Niocotiana, and Glycine, culminating at 0.75 to $1 \mathrm{~mol} \mathrm{~m}^{-2} \mathrm{~s}^{-1} \mathrm{bar}^{-1}$ (Bernacchi et al., 2002). However, for Arabidopsis thaliana, which is closely related to canola, the $g_{\mathrm{m}}$ remained unchanged over a temperature gradient, reaching a maximum of $0.22 \mathrm{~mol} \mathrm{~m}^{-2} \mathrm{~s}^{-1} \mathrm{bar}^{-1}$ at $25^{\circ} \mathrm{C}$ and then decreasing. Similarly, reduced $g_{\mathrm{m}}$ was found under a high temperature, but there was no significant effect under drought. Previous studies have reported that $g_{\mathrm{m}}$ frequently, but not always, decreased in response to a water deficit (Flexas et al., 2008; Warren, 2008; Barbour and Kaiser, 2016). There is a strong relationship between $g_{s}$ and $g_{\mathrm{m}}$ as the amount of $\mathrm{CO}_{2}$ in the sub-stomatal cavity should affect the fraction of $\mathrm{CO}_{2}$ reaching the chloroplast stroma through the $C_{\mathrm{i}}$, cell membranes, and cytoplasm (Olsovska et al., 2016). In general, drought triggers stomatal closure; consequently, mesophyll conductance would decrease. However, recent studies have shown that $g_{\mathrm{s}}$ and $g_{\mathrm{m}}$ conductance's can be uncoupled although environmental conditions might alter them in the same way (Barbour et al., 2016; Gago et al., 2016). Théroux-Rancourt et al. (2015) found that the $g_{\mathrm{m}}$ of hybrid poplar cuttings exposed to drought declined, but this response was delayed when compared to that for $g_{s}$. In contrast, Barbour and Kaiser (2016) observed no effect on $g_{\mathrm{m}}$ under drought conditions when an adequate nitrogen supply was made available. The unchanged $g_{\mathrm{m}}$ under the moisture deficit in the current study might have been caused by a physiological acclimation in response to the stomatal closure and the decline of the $C_{\mathrm{i}}$, facilitating $\mathrm{CO}_{2}$ diffusion to the carboxylation site and preventing a shortage of substrate (Flexas et al., 2010). Such adjustment mechanisms are still unclear. They are more likely anatomical and morphological (i.e., the chloroplast position, leaf mass area; Milla-Moreno et al., 2016). Also, Momayyezi and Guy (2017, 2018) reported a substantial role for carbonic anhydrase in influencing $g_{\mathrm{m}}$.

Apart from the $\mathrm{CO}_{2}$ diffusion limitations, photosynthetic biochemical limitations have been reported to be remarkably heat-sensitive; however, drought has had a lesser effect (Flexas et al., 2006; Galmés et al., 2007). Indeed, previous 

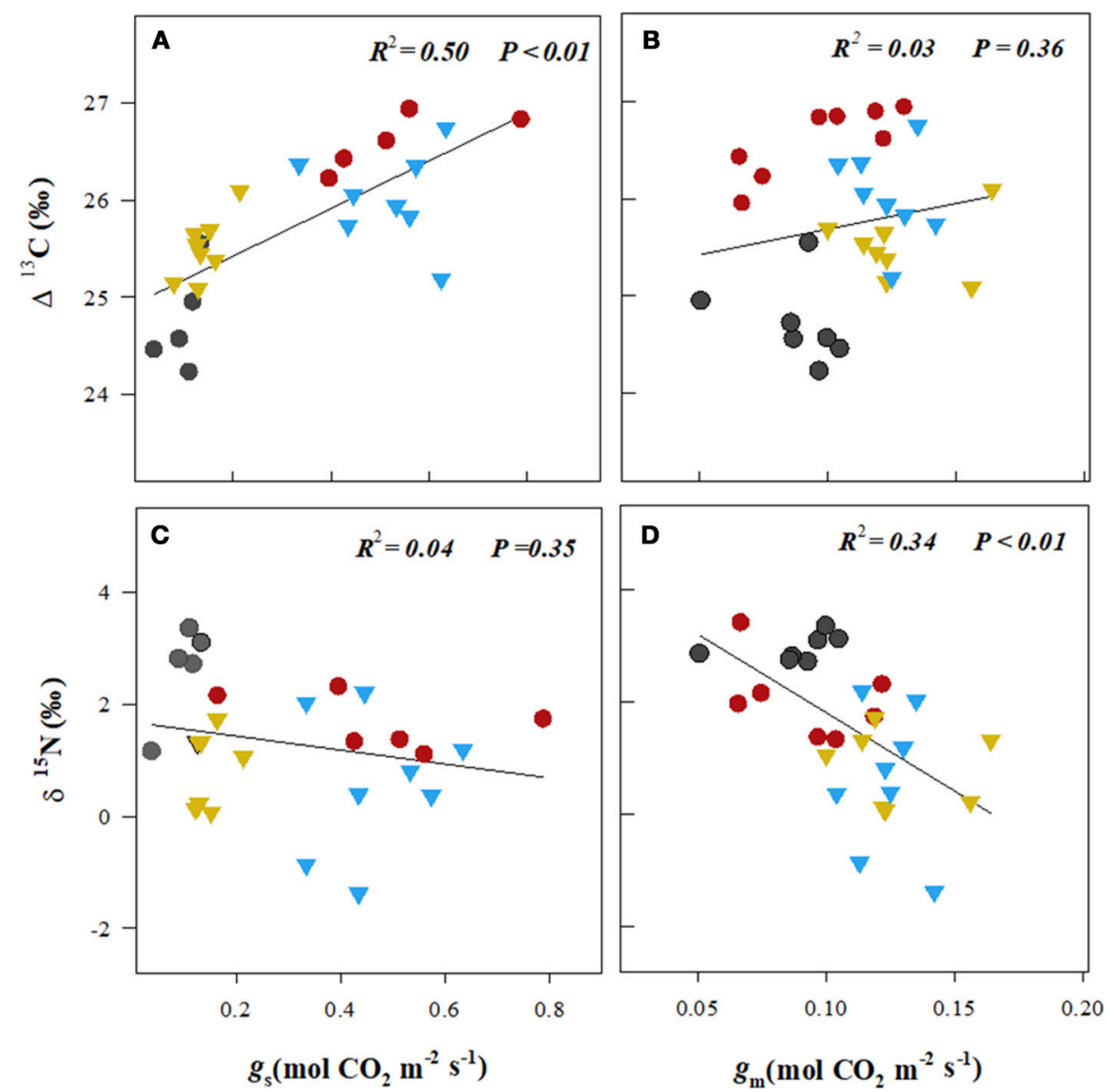

FIGURE 5 | The relationships between leaf stomatal conductance $\left(g_{\mathrm{s}}, \mathbf{A}, \mathbf{C}\right)$ and mesophyll conductance $\left(g_{\mathrm{m}}, \mathbf{B}, \mathbf{D}\right)$ of $\mathrm{CO}_{2}$ and the leaf isotopic composition of carbon $\left(\Delta^{13} \mathrm{C}\right)$ and nitrogen $\left(\delta^{15} \mathrm{~N}\right)$. $\nabla$, well-watered plants $\left(\mathrm{WW}, 23^{\circ} \mathrm{C}\right) ; \nabla$, drought $\left(\mathrm{D}, 23^{\circ} \mathrm{C}\right)$; $\boldsymbol{\bullet}$, heat $\left(\mathrm{H}, 29^{\circ} \mathrm{C}\right)$; $\mathbf{O}$, heat $+\operatorname{drought}\left(\mathrm{HD}, 29^{\circ} \mathrm{C}\right)$. The lines were fitted by regression using all the points in a plot.
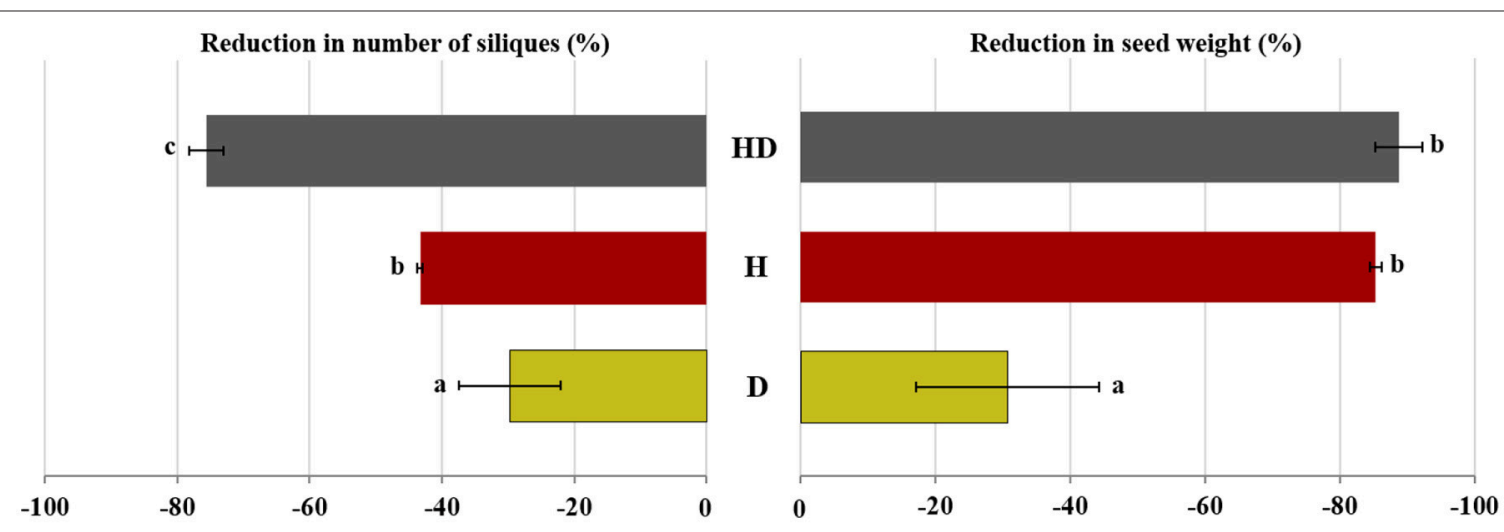

FIGURE 6 | The percentage reduction in the seed weight and number of silique for the plants subjected to the drought $(D)$, heat $(H)$, and heat + drought $(H D)$ treatments compared to the plants subjected to the control treatment. The treatments that were significantly different at $p<0.05$ are labeled with different letters (Tukey's HSD).

studies have found that a severe water deficit has a limited effect or no effect on biochemical limitations rates $\left(V_{c \operatorname{cmax}}\right.$ and $\left.J\right)$ compared to its effect on stomatal limitations (Demirevska et al., 2009; Killi and Haworth, 2017). These findings are in agreement with the trends of nonsignificant effects of drought treatments on the $V_{c \max }$ and 


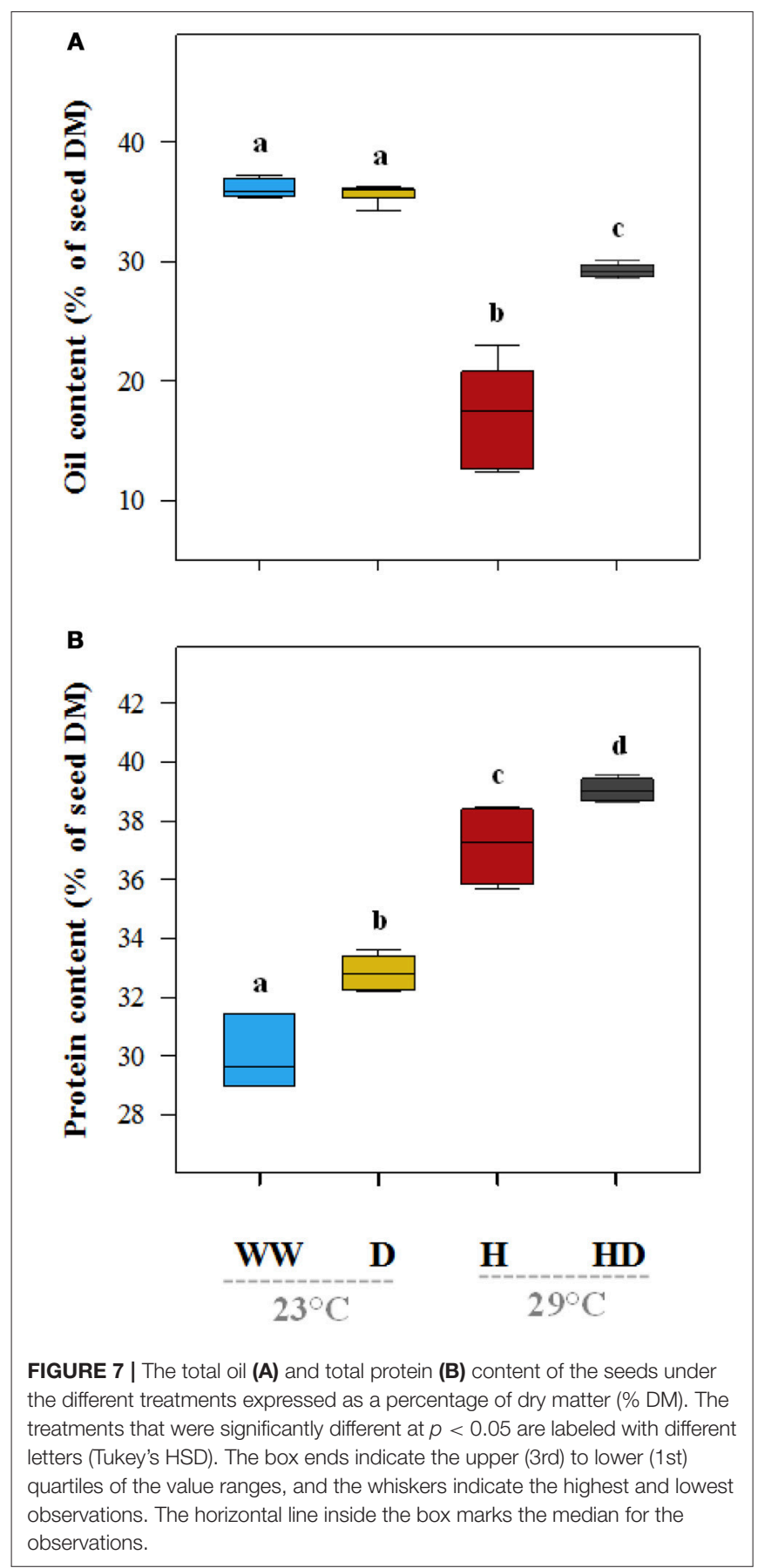

the $J$ but significant decreases to both under heat treatments. Under the heat + drought treatment, the $V_{c \max }$ and the $J$ decreased further, showing the cumulative effects of the combined stressors; however, the $J / V_{\mathrm{cmax}}$ ratio did not change over the treatments (data not shown). Changes in the $J / V_{\text {cmax }}$ ratio have been observed under adverse conditions. This could be the result of resource allocation, particularly nitrogen, to RuBisCO carboxylation or the electron transfer to optimize the photosynthetic assimilation rate (Hikosaka et al., 2006).
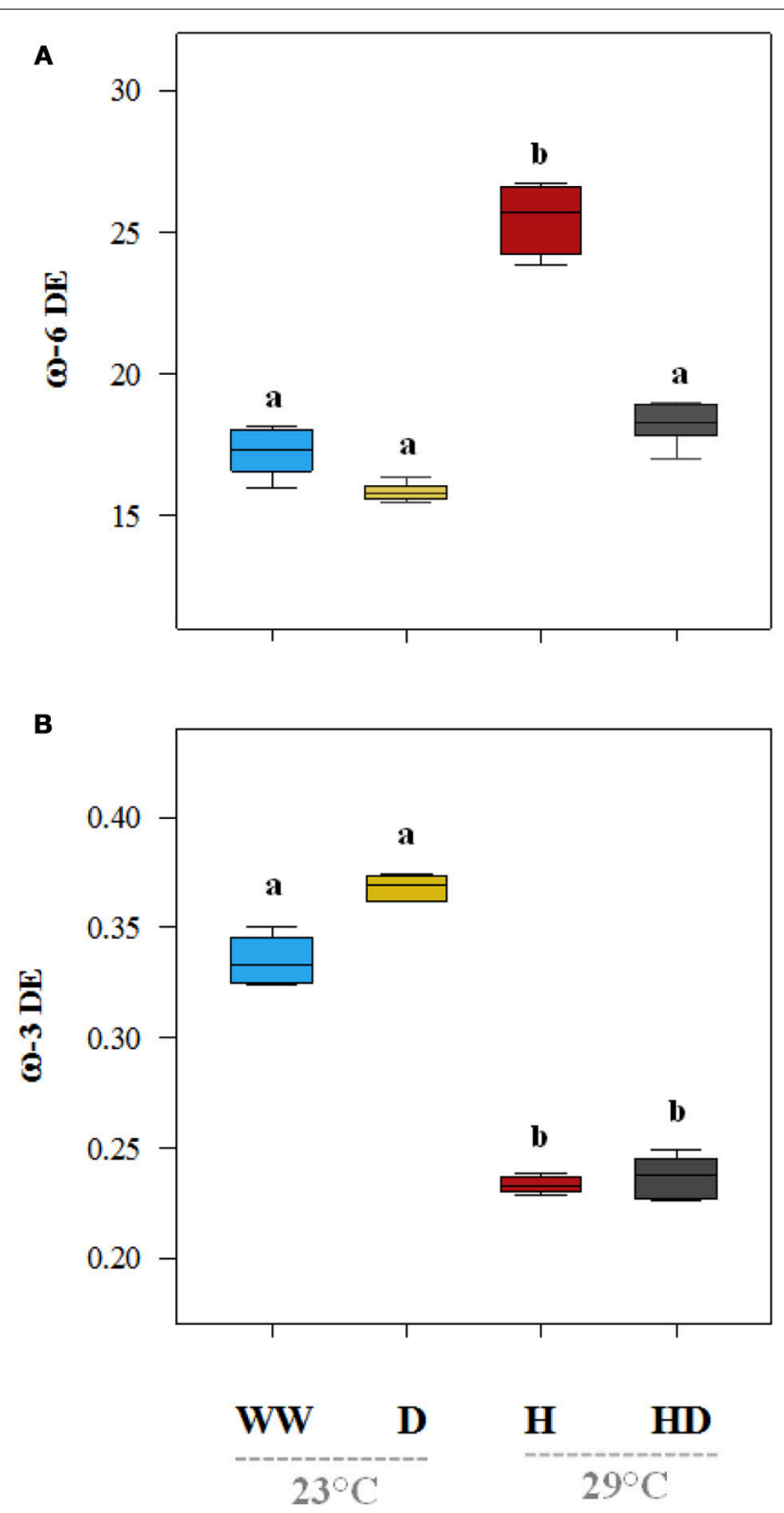

FIGURE 8 | The desaturation efficiency (DE) of the Omega $6(\omega-6)$ (A) and Omega $3(\omega-3)(\mathbf{B})$ of the seed fatty acids under the different treatments. The DE values that were significantly different at $p<0.05$ are labeled with different letters (Tukey's HSD). The box ends indicate the upper (3rd) to lower (1st) quartiles of the value ranges, and the whiskers indicate the highest and lowest observations. The horizontal line inside the box marks the median for the observations.

\section{Carbon and Nitrogen-Use Efficiency}

The results of this study showed that the $\Delta^{13} \mathrm{C}$ response to stress treatments paralleled the trends seen in the $g_{\mathrm{s}}$ response. The ratio of the $C_{\mathrm{i}}$ to the ambient $\mathrm{CO}_{2}$ fraction $\left(C_{\mathrm{i}} / C_{\mathrm{a}}\right)$ is the main driver of the $\Delta^{13} \mathrm{C}$ variation in $\mathrm{C}_{3}$ terrestrial plants. This is influenced mainly by stomatal conductance (Farquhar et al., 1982). It is attributable to the shared path of the transpired $\mathrm{H}_{2} \mathrm{O}$ and the inbound $\mathrm{CO}_{2}$ fluxes, which stop in 


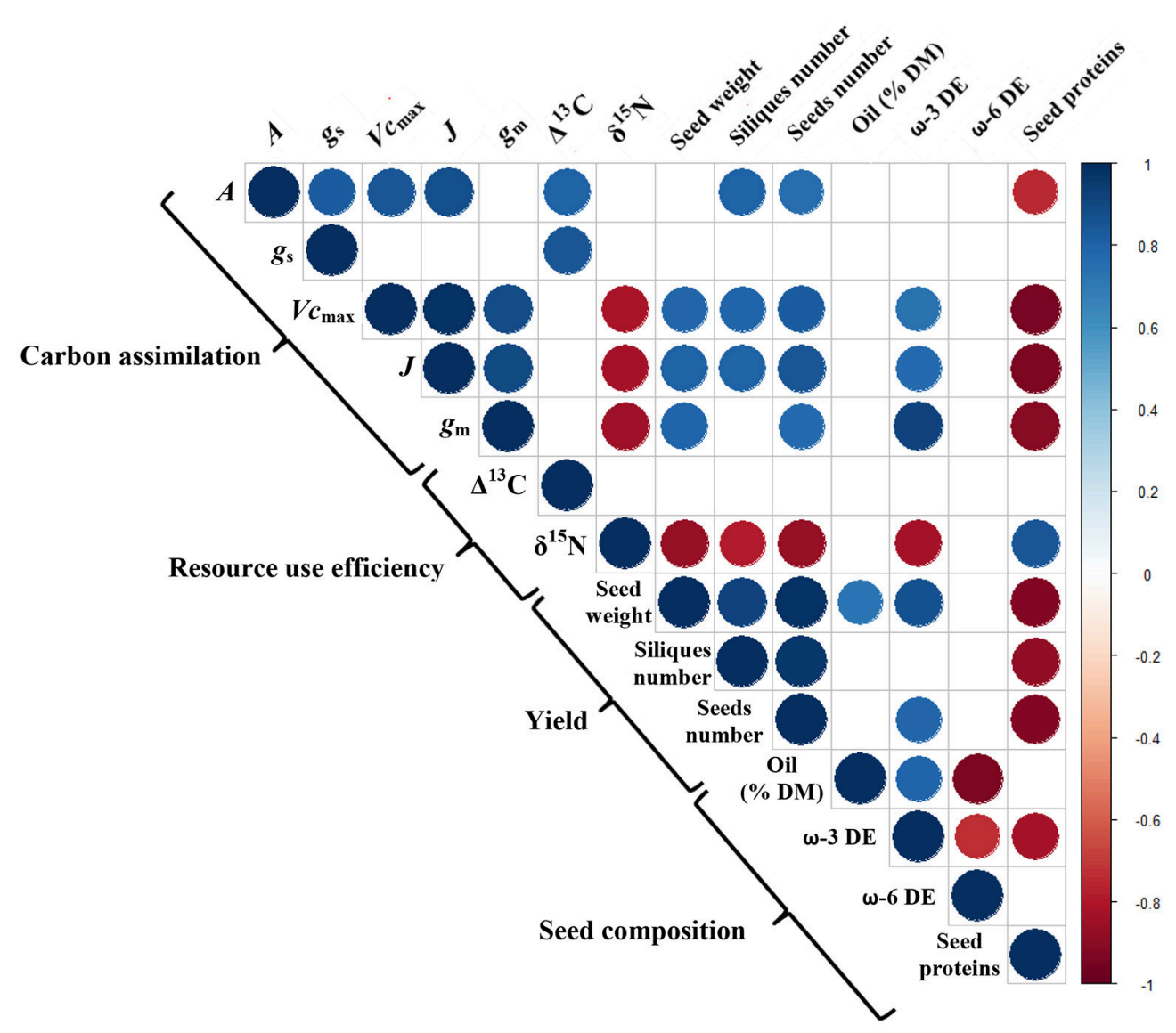

FIGURE 9 | The Pearson's correlation coefficients for the measured traits across all the treatments. The blue and red circles denote significant positive and negative correlations, respectively $(p=0.05)$, and the empty cases refer to non-significant correlations. The color gradient is proportional to the correlation coefficient.

both directions when the stomata are closed in response to a water deficit. Several studies of plants in pots and in fields have demonstrated a strong relationship between water availability and the leaf carbon isotopic composition (Swap et al., 2004; Hartman and Danin, 2010; Cabrera-Bosquet et al., 2011). Given the environmental stability under which this experiment was conducted, the observed $\Delta^{13} \mathrm{C}$ variations were attributed solely to soil moisture availability. Under the optimal water supply, an increase in the air temperature did not affect the leaf $\Delta^{13} \mathrm{C}$. However, $\Delta^{13} \mathrm{C}$ was lowest under heat + drought treatment compared to drought alone, suggesting a synergistic effect of the two stressors ("- synergistic" according to Piggott et al., 2015) which is supported by the significant $\mathrm{H} \times \mathrm{D}$ interaction effect on $\Delta^{13} \mathrm{C}(P<0.001)$. An increased water use-efficiency (i.e., lower $\Delta^{13} \mathrm{C}$ ) under heat + drought reflects a scenario that goes beyond the effects of single stresses, whereby a higher canopy temperature results from drought-induced stomatal closure in combination with heat treatment.

Several studies conducted in natural ecosystems along a rainfall gradient (in addition to a temperature gradient) showed higher $\delta^{15} \mathrm{~N}$ values in $\mathrm{C}_{3}$ plants. In the current experiment, the $\delta^{15} \mathrm{~N}$ values were influenced more by heat than drought. It is unclear, therefore, whether the variation in $\delta^{15} \mathrm{~N}$ enrichment was the result of heat or drought or a combination of both. In contrast, in the natural stands, the $\delta^{15} \mathrm{~N}$ values were higher in high nitrogen soils, and the nitrogen availability was higher in the warm and dry areas (Craine et al., 2009). Given the uniform soil characteristics and the short-term nature of this experiment, it is unlikely that heat and moisture deficits could influence the ${ }^{15} \mathrm{~N}$ vs. ${ }^{14} \mathrm{~N}$ fractions in the soil and, subsequently, the variations in $\delta^{15} \mathrm{~N}$ observed in the leaves (Hartman and Danin, 2010). Therefore, it is proposed that the observed $\delta^{15} \mathrm{~N}$ variation in the current experiment resulted from plant internal fractionation during the physiological processes that occurred during the nitrogen uptake, assimilation, allocation, and remobilization (Evans, 2001). In plant roots, the assimilation of nitrogen occurs for $\mathrm{NH}_{4}^{+}$through the glutamine synthetase-glutamate synthase (GS-GOGAT) pathway. However, the assimilation of $\mathrm{NO}_{3}^{-}$ occurs in the roots and the leaves by nitrate reductase (NR) and the nitrite reductase $(\mathrm{NiR})$ pathway, producing $\mathrm{NH}_{4}^{+}$, which is subsequently assimilated through the GS-GOGAT reactions (Evans, 2001). Given that the $\delta^{15} \mathrm{~N}$ of the leaves but not the roots was measured, the site of the nitrogen fractionation in $B$. napus remains inconclusive. Thus, a thorough understanding of 
B. napus metabolic pathways for the nitrogen uptake $\left(\mathrm{NO}_{3}^{-}\right.$and $\mathrm{NH}_{4}^{+}$)-, assimilation-, allocation-, and remobilization-inducing $\delta^{15} \mathrm{~N}$ variations would provide more information about plant nitrogen use, in turn a time-integrated measure of crop nitrogenuse efficiency.

\section{Seed Yield}

Heat stress during flowering was reported to reduce seed yield markedly by altering the gametogenesis (from meiosis to maturity), embryo sac differentiation, fertilization, and postfertilization structures, such as the growth of the endosperm and the embryo (Wahid et al., 2007; Barnabás et al., 2008; Rieu et al., 2017), particularly in cool environment crops like $B$. napus. A higher sensitivity to heat for the female reproductive structures (ovary and embryo sac) than for the male structures was reported (Peet et al., 1998). In contrast, other studies have found pollen to be the most sensitive to heat (Saini and Aspinall, 1982). Drought also alters the reproduction and seed set in crops; however, the magnitude of this effect is generally less than that of heat. Drought stress lessens the available nutrients and photo-assimilation reserves that are essential for the development of reproductive structures (e.g., pollen tube elongation; see Barnabás et al., 2008).

As was hypothesized, the results showed a prevalent effect of heat, over that of drought, on yield as the seed weight of the plants exposed to heat reduced by $84 \%$ (vs. $31 \%$ for drought) and the silique number decreased by $43 \%$. Angadi et al. (2000) observed that heat stress during the flowering stage, as opposed to the seed filling stage, had a pronounced effect on the B. napus yields. A threshold temperature close to $30^{\circ} \mathrm{C}$ during flowering has been reported as critical for yields for many herbaceous crops. The temperature threshold depends also on the plant species and the duration of exposure. For example, threshold temperatures range is $26^{\circ} \mathrm{C}$ for wheat (Stone and Nicolas, 1994) and $45^{\circ} \mathrm{C}$ for cotton (Ur Rahman et al., 2004), but for Brassica species, it is $\sim 29.5^{\circ} \mathrm{C}$ (Morrison and Stewart, 2002). The results showed a considerable effect of heat at $29^{\circ} \mathrm{C}$ on seed yield, suggesting that the temperature threshold is much lower for canola (Gan et al., 2004; Aksouh-Harradj et al., 2006).

\section{Oil Yield and Composition}

Oil is the most profitable product from canola seed processing, and its content and composition are affected by environmental factors (Jensen et al., 1996; Si et al., 2003). Seed oil stems mostly from photosynthetic carbon assimilation of leaves and green silique walls, later carbohydrates converted into triacylglycerol through a metabolic pathway occurring in the plastid, cytosol, and endoplasmic reticula (Baud and Lepiniec, 2010; and references therein). The effects of drought and heat on the oil content in oilseed crops have varied remarkably and have most likely been the result of a high $\mathrm{G} \times \mathrm{E}$ interaction (Pritchard et al., 2000; Sinaki, 2009; Zhang et al., 2014). Champolivier and Merrien (1996) reported a 6-12\% decrease in oil content in the B. napus when the plants were subjected to a water deficit during flowering and silique development, but Aslam et al. (2009) reported a mere $3.2 \%$ reduction. In a different field study, Zarei et al. (2010) found no differences in canola oil content (an average of 37.27\%) with or without irrigation. Similar to the observations made under drought conditions, Zhang et al. (2014) reported a significant effect of heat on oil content, which decreased by $52.5 \%$. The results of this study were similar to those of Zhang et al. (2014). Heat, through its effect on the enzymatic panel involved in the lipid biosynthesis pathways, has been reported to decrease oil content (Iyer et al., 2008; Baud and Lepiniec, 2010).

In addition, the silique walls, along with the leaves during the post-flowering stages, are significant sources of photosynthates (Aschan and Pfanz, 2003; Bennett et al., 2011; Hua et al., 2012). Thus, abiotic stressors during flowering would affect silique development and subsequently reduce the available photoassimilates for triacylglycerol biosynthesis and oil accumulation in the seeds. In addition, oxygen availability in silique was also cited as a limiting factor in seed development (Porterfield et al., 2000). Vigeolas et al. (2003) reported that a low oxygen content in B. napus seeds resulted in reductions in the adenosine triphosphate (ATP) level and the triacylglycerol content. Similarly, Rolletschek et al. (2007) observed a negative correlation between the ambient temperatures and the oxygen levels in sunflower seeds, a relationship that affects oil composition.

As was hypothesized, heat noticeably altered the oil profile, but drought had a marginal effect. Previous studies on heat have reported changes in the oil composition, particularly the fatty acids, and protein content in oil seed crops (Dornbos and Mullen, 1992; Flagella et al., 2002; Wang and Frei, 2011). This effect has been attributed to the enzymes involved in biosynthesis and the conversion of fatty acids in various cellular compartments (Flagella et al., 2002; Di Caterina et al., 2007; Hernández et al., 2009). For example, Martínez-Rivas et al. (2003) found that in sunflowers, the activity of oleate desaturase, an enzyme involved in the desaturation of fatty acids in oilseeds, was altered by heat. Moreover, oil composition has been shown to be influenced by the action of abiotic stressors on the transport of fatty acids through various organelles, particularly from plastids to cytosol, where oleic acid (18:1) is converted into linoleic acids (18:2) and linolenic acids (18:3) (Browse and Somerville, 1991). In general, the fraction of polyunsaturated fatty acids decreased; however, the fraction of saturated fatty acids and, concurrently, oleic acid (mono-unsaturated) increased in response to stressors (Pritchard et al., 2000; Wang and Frei, 2011). The results of the current study were similar to those previously seen for heat conditions, which increased the proportion of saturated fatty acids, but not for drought, which increased the relative content of unsaturated fatty acids (Aslam et al., 2009).

Along with triacylglycerol, seed proteins represent a major form of energy reserves in the Brassica species, and their respective contents are negatively correlated (Grami et al., 1977; Jensen et al., 1996). Thus, stressors decreasing the oil content in seeds would concurrently increase the protein fraction (Henry and MacDonald, 1978; Rossato et al., 2001; Rathke et al., 2006). Overall, the results of this study are in agreement with these previous findings although the drought treatment increased the seed proteins without affecting the oil content. For the most part, heat exceeded the effect of drought in augmenting the seed protein content (e.g., heat shocks proteins as chaperones; Kotak et al., 2007) but not the osmoprotectants (polyamine, 
glycine betaine, and proline; Singh et al., 2015). Under the heat treatment, the well-watered plants might maintain the optimal nitrogen uptake and accumulation in the vegetative parts, subsequently nitrogen remobilized from the senescent tissue to the seeds. Given that the seed number was considerably reduced by heat, the nitrogen supply could have been superior to the demand, thus boosting the seed protein content. Lohaus and Moellers (2000) demonstrated that the external nitrate supply is determinant of the total amino acid content of the phloem sap of leaves and is positively correlated with the seed protein content in two B. napus cultivars. The partitioning of the oil and protein content was under $\mathrm{G} \times \mathrm{E}$ control, and the molecular basis of this trade-off is still unclear (Si et al., 2003; Chao et al., 2017).

\section{CONCLUSIONS}

Overall, the results of this study showed a divergence between the effects of drought, heat, and heat + drought on canola seed yield and oil quality. Drought affected the carbon assimilation rate mainly through the limitation of $\mathrm{CO}_{2}$ diffusion through the stomata and the seed yield components. The effects of the heat conditions were clearly manifested in the alteration of the reproductive organs and process, leading to a substantial reduction in the seed yield and the number of siliques. To a lesser extent, heat impaired the internal $\mathrm{CO}_{2}$ diffusion and the RuBisCO carboxylation and regeneration. This was most likely the result of thermal damage to the enzymes involved in photosynthetic assimilation. Similarly, heat had a prevailing effect over drought on seed composition, which is greatly influenced by the conversion and transport of photo-assimilates to the seeds, in turn higher levels of saturated fatty oils. Such higher levels of saturated fat under warmer climates could affect industrially relevant traits: the taste, freshness, and shelf life of

\section{REFERENCES}

Aksouh-Harradj, N., Campbell, L., and Mailer, R. (2006). Canola response to high and moderately high temperature stresses during seed maturation. Can. J. Plant Sci. 86, 967-980. doi: 10.4141/P05-130

Alexander, L., Zhang, X., Peterson, T., Caesar, J., Gleason, B., Klein Tank, A., et al. (2006). Global observed changes in daily climate extremes of temperature and precipitation. J. Geophys. Res. 111:D0510. doi: 10.1029/2005JD006290

Angadi, S., Cutforth, H., Miller, P., McConkey, B., Entz, M., Brandt, S., et al. (2000). Response of three Brassica species to high temperature stress during reproductive growth. Can. J. Plant Sci. 80, 693-701. doi: 10.4141/P99-152

AOAC (2003). Official Methods of Analysis of AOAC International. Gaithersburg, MD: AOAC International.

Aschan, G., and Pfanz, H. (2003). Non-foliar photosynthesis-a strategy of additional carbon acquisition. Flora Morphol. Distrib. Funct. Ecol. Plants 198, 81-97. doi: 10.1078/0367-2530-00080

Aslam, M., Nelson, M., Kailis, S., Bayliss, K., Speijers, J., and Cowling, W. (2009). Canola oil increases in polyunsaturated fatty acids and decreases in oleic acid in drought-stressed Mediterranean-type environments. Plant Breed. 128, 348-355. doi: 10.1111/j.1439-0523.2008.01577.x

Bansal, S., Hallsby, G., Löfvenius, M. O., and Nilsson, M.-C. (2013). Synergistic, additive and antagonistic impacts of drought and herbivory on Pinus sylvestris: leaf, tissue and whole-plant responses and recovery. Tree Physiol. 33, 451-463. doi: 10.1093/treephys/tpt019 canola oil. The adverse effects of moderate to severe drought can be mitigated by irrigation and/or using genotypes with greater water-use efficiency. However, heat requires the breeding of heat tolerant canola as a major tool to manage the harmful effects of such environments. Such breeding efforts could target the carboxylation capacity and diffusion of $\mathrm{CO}_{2}$ along the mesophyll pathway as well as the tolerance of the reproductive organs for elevated temperatures.

\section{AUTHOR CONTRIBUTIONS}

RS and RE conceived and designed the experiment. RE conducted the experiment, analyzed data, interpreted results, and drafted the manuscript.

\section{ACKNOWLEDGMENTS}

The authors would like to thank Sally Vail (Brassica napus breeder) for providing canola seed; Eiji Nambara, University of Toronto for ABA analysis; and Branimir Gjetvaj for technical assistance with greenhouse study. This research was supported to RS by the Agriculture Development Fund, Saskatchewan Ministry of Agriculture and the Canada-Saskatchewan Growing Forward 2 bi-lateral agreement. In addition, the project received funding support from SaskCanola, Saskatchewan Canola Development Commission. RE is a Visiting Research Scientist at AAFC.

\section{SUPPLEMENTARY MATERIAL}

The Supplementary Material for this article can be found online at: https://www.frontiersin.org/articles/10.3389/fpls.2018. 01224/full\#supplementary-material

Barbour, M. M., Evans, J. R., Simonin, K. A., and Caemmerer, S. (2016). Online $\mathrm{CO}_{2}$ and $\mathrm{H}_{2} \mathrm{O}$ oxygen isotope fractionation allows estimation of mesophyll conductance in $\mathrm{C}_{4}$ plants, and reveals that mesophyll conductance decreases as leaves age in both $\mathrm{C}_{4}$ and $\mathrm{C}_{3}$ plants. New Phytol. 210, 875-889. doi: 10.1111/nph.13830

Barbour, M. M., and Kaiser, B. N. (2016). The response of mesophyll conductance to nitrogen and water availability differs between wheat genotypes. Plant Sci. 251, 119-127. doi: 10.1016/j.plantsci.2016.03.012

Barnabás, B., Jäger, K., and Fehér, A. (2008). The effect of drought and heat stress on reproductive processes in cereals. Plant Cell Environ. 31, 11-38. doi: 10.1111/j.1365-3040.2007.01727.x

Battisti, D. S., and Naylor, R. L. (2009). Historical warnings of future food insecurity with unprecedented seasonal heat. Science 323, 240-244. doi: 10.1126/science.1164363

Baud, S., and Lepiniec, L. (2010). Physiological and developmental regulation of seed oil production. Prog. Lipid Res. 49, 235-249. doi: 10.1016/j.plipres.2010.01.001

Bennett, E. J., Roberts, J. A., and Wagstaff, C. (2011). The role of the pod in seed development: strategies for manipulating yield. New Phytol. 190, 838-853. doi: 10.1111/j.1469-8137.2011.03714.x

Bernacchi, C. J., Portis, A. R., Nakano, H., von Caemmerer, S., and Long, S. P. (2002). Temperature response of mesophyll conductance. Implications for the determination of Rubisco enzyme kinetics and for limitations to photosynthesis in vivo. Plant Physiol. 130, 1992-1998. doi: 10.1104/pp.008250 
Browse, J., and Somerville, C. (1991). Glycerolipid synthesis: biochemistry and regulation. Annu. Rev. Plant Biol. 42, 467-506. doi: 10.1146/annurev.pp.42.060191.002343

Cabrera-Bosquet, L., Albrizio, R., Nogués, S., and Araus, J. L. (2011). Dual $\Delta^{13} \mathrm{C} / \delta^{18} \mathrm{O}$ response to water and nitrogen availability and its relationship with yield in field-grown durum wheat. Plant Cell Environ. 34, 418-433. doi: 10.1111/j.1365-3040.2010.02252.x

Champolivier, L., and Merrien, A. (1996). Effects of water stress applied at different growth stages to Brassica napus L. var. oleifera on yield, yield components and seed quality. Eur. J. Agron. 5, 153-160. doi: 10.1016/S1161-0301(96)02004-7

Chao, H., Wang, H., Wang, X., Guo, L., Gu, J., Zhao, W., et al. (2017). Genetic dissection of seed oil and protein content and identification of networks associated with oil content in Brassica napus. Sci. Rep. 7:46295. doi: $10.1038 /$ srep 46295

Craine, J. M., Elmore, A. J., Aidar, M. P., Bustamante, M., Dawson, T. E., Hobbie, E. A., et al. (2009). Global patterns of foliar nitrogen isotopes and their relationships with climate, mycorrhizal fungi, foliar nutrient concentrations, and nitrogen availability. New Phytol. 183, 980-992. doi: 10.1111/j.1469-8137.2009.02917.x

Crawford, A. J., McLachlan, D. H., Hetherington, A. M., and Franklin, K. A. (2012). High temperature exposure increases plant cooling capacity. Curr. Biol. 22, 396-397. doi: 10.1016/j.cub.2012.03.044

Darling, E. S., McClanahan, T. R., and Côté, I. M. (2010). Combined effects of two stressors on Kenyan coral reefs are additive or antagonistic, not synergistic. Conserv. Lett. 3, 122-130. doi: 10.1111/j.1755-263X.2009.00089.x

Demirevska, K., Zasheva, D., Dimitrov, R., Simova-Stoilova, L., Stamenova, M., and Feller, U. (2009). Drought stress effects on RuBisCO in wheat: changes in the RuBisCO large subunit. Acta Physiol. Plant. 31:1129. doi: 10.1007/s11738-009-0331-2

Di Caterina, R., Giuliani, M. M., Rotunno, T., De Caro, A., and Flagella, Z. (2007). Influence of salt stress on seed yield and oil quality of two sunflower hybrids. Ann. Appl. Biol. 151, 145-154. doi: 10.1111/j.1744-7348.2007.00165.x

Dornbos, D., and Mullen, R. (1992). Soybean seed protein and oil contents and fatty acid composition adjustments by drought and temperature. J. Am. Oil Chem. Soc. 69, 228-231. doi: 10.1007/BF02635891

Ethier, G., and Livingston, N. (2004). On the need to incorporate sensitivity to $\mathrm{CO}_{2}$ transfer conductance into the Farquhar-von CaemmererBerry leaf photosynthesis model. Plant Cell Environ. 27, 137-153. doi: $10.1111 /$ j.1365-3040.2004.01140.x

Ethier, G. J., Livingston, N. J., Harrison, D. L., Black, T. A., and Moran, J. A. (2006). Low stomatal and internal conductance to $\mathrm{CO}_{2}$ versus RuBisCO deactivation as determinants of the photosynthetic decline of ageing evergreen leaves. Plant Cell Environ. 29, 2168-2184. doi: 10.1111/j.1365-3040.2006.01590.x

Evans, J. R., Kaldenhoff, R., Genty, B., and Terashima, I. (2009). Resistances along the $\mathrm{CO}_{2}$ diffusion pathway inside leaves. J. Exp. Bot. 60, 2235-2248. doi: $10.1093 / \mathrm{jxb} / \mathrm{erp} 117$

Evans, R. D. (2001). Physiological mechanisms influencing plant nitrogen isotope composition. Trends Plant Sci. 6, 121-126. doi: 10.1016/S1360-1385(01)01889-1

FAO (2017). FAOSTAT. Available online at: http://www.fao.org/faostat/en/\# data/QC. Rapeseed production, 2014; Crops/Regions/World list/Production Quantity (pick lists) (Accessed December 22, 2017).

Farquhar, G. D., Ehleringer, J. R., and Hubick, K. T. (1989). Carbon isotope discrimination and photosynthesis. Annu. Rev. Plant Physiol. Plant Mol. Biol. 40, 503-537. doi: 10.1146/annurev.pp.40.060189.002443

Farquhar, G. D., O'leary, M. H., and Berry, J. A. (1982). On the relationship between carbon isotope discrimination and the intercellular carbon dioxide concentration in leaves. Aust. J. Plant Physiol. 9, 121-137. doi: 10.1071/PP9820121

Farquhar, G. D., von Caemmerer, S., and Berry, J. A. (1980). A biochemical model of photosynthetic $\mathrm{CO}_{2}$ assimilation in leaves of $\mathrm{C}_{3}$ species. Planta $149,78-90$. doi: 10.1007/BF00386231

Feller, U., and Vaseva, I. I. (2014). Extreme climatic events: impacts of drought and high temperature on physiological processes in agronomically important plants. Front. Environ. Sci. 2:39. doi: 10.3389/fenvs.2014. 00039

Flagella, Z., Rotunno, T., Tarantino, E., Di Caterina, R., and De Caro, A. (2002). Changes in seed yield and oil fatty acid composition of high oleic sunflower
(Helianthus annuus L.) hybrids in relation to the sowing date and the water regime. Eur. J. Agron. 17, 221-230. doi: 10.1016/S1161-0301(02)00012-6

Flexas, J., Galmés, J., Gallé, A., Gulías, J., Pou, A., Ribas-Carbo, M., et al. (2010). Improving water use efficiency in grapevines: potential physiological targets for biotechnological improvement. Aust. J. Grape Wine Res. 16, 106-121. doi: 10.1111/j.1755-0238.2009.00057.x

Flexas, J., and Medrano, H. (2002). Drought-inhibition of photosynthesis in $\mathrm{C}_{3}$ plants: stomatal and non-stomatal limitations revisited. Ann. Bot. 89, 183-189. doi: $10.1093 / \mathrm{aob} / \mathrm{mcf027}$

Flexas, J., Ribas-Carbó, M., Bota, J., Galmés, J., Henkle, M., Martínez-Cañellas, S., et al. (2006). Decreased RuBisCO activity during water stress is not induced by decreased relative water content but related to conditions of low stomatal conductance and chloroplast $\mathrm{CO}_{2}$ concentration. New Phytol. 172, 73-82. doi: 10.1111/j.1469-8137.2006.01794.x

Flexas, J., Ribas-Carbó, M., Diaz-Espejo, A., Galmés, J., and Medrano, H. (2008). Mesophyll conductance to $\mathrm{CO}_{2}$ : current knowledge and future prospects. Plant Cell Environ. 31, 602-621. doi: 10.1111/j.1365-3040.2007.01757.x

Gago, J., Daloso Dde, M., Figueroa, C. M., Flexas, J., Fernie, A. R., and Nikoloski, Z. (2016). Relationships of leaf net photosynthesis, stomatal conductance, and mesophyll conductance to primary metabolism: a multispecies meta-analysis approach. Plant Physiol. 171, 265-279. doi: 10.1104/pp.15.01660

Galmés, J., Medrano, H., and Flexas, J. (2007). Photosynthetic limitations in response to water stress and recovery in Mediterranean plants with different growth forms. New Phytol. 175, 81-93. doi: 10.1111/j.1469-8137.2007.02087.x

Gan, Y., Angadi, S. V., Cutforth, H., Potts, D., Angadi, V. V., and McDonald, C. L. (2004). Canola and mustard response to short periods of temperature and water stress at different developmental stages. Can. J. Plant Sci. 84, 697-704. doi: 10.4141/P03-109

Grami, B., Stefansson, B. R., and Baker, R. J. (1977). Genetics of protein and oil content in summer rape: heritability number of effective factors and correlations. Can. J. Plant Sci. 57, 937-943. doi: 10.4141/cjps77-134

Handley, L. L., Austin, A., Stewart, G., Robinson, D., Scrimgeour, C., Raven, J., et al. (1999). The ${ }^{15} \mathrm{~N}$ natural abundance $\left(\delta^{15} \mathrm{~N}\right)$ of ecosystem samples reflects measures of water availability. Funct. Plant Biol. 26, 185-199. doi: $10.1071 /$ PP98146

Hartman, G., and Danin, A. (2010). Isotopic values of plants in relation to water availability in the Eastern Mediterranean region. Oecologia 162, 837-852. doi: 10.1007/s00442-009-1514-7

Henry, J. L., and MacDonald, K. B. (1978). The effects of soil and fertilizer nitrogen and moisture stress on yield, oil and protein content of rape. Can. J. Soil Sci. 58, 303-310. doi: 10.4141/cjss78-036

Hernández, M. L., Padilla, M. N., Mancha, M., and Martínez-Rivas, J. M. (2009). Expression analysis identifies FAD2-2 as the olive oleate desaturase gene mainly responsible for the linoleic acid content in virgin olive oil. J. Agric. Food Chem. 57, 6199-6206. doi: 10.1021/jf900678z

Heydarian, Z., Yu, M., Gruber, M., Glick, B. R., Zhou, R., and Hegedus, D. D. (2016). Inoculation of soil with plant growth promoting bacteria producing 1-Aminocyclopropane-1-Carboxylate Deaminase expression of the corresponding acdS gene in transgenic plants increases salinity tolerance in Camelina sativa. Front. Microbiol. 7:1966. doi: 10.3389/fmicb.2016.01966

Hikosaka, K., Ishikawa, K., Borjigidai, A., Muller, O., and Onoda, Y. (2006). Temperature acclimation of photosynthesis: mechanisms involved in the changes in temperature dependence of photosynthetic rate. J. Exp. Bot. 57, 291-302. doi: 10.1093/jxb/erj049

Hua, W., Li, R. J., Zhan, G. M., Liu, J., Li, J., Wang, X. F., et al. (2012). Maternal control of seed oil content in Brassica napus: the role of silique wall photosynthesis. Plant J. 69, 432-444. doi: 10.1111/j.1365-313X.2011.04802.x

Iyer, V. V., Sriram, G., Fulton, D. B., Zhou, R., Westgate, M. E., and Shanks, J. (2008). Metabolic flux maps comparing the effect of temperature on protein and oil biosynthesis in developing soybean cotyledons. Plant Cell Environ. 31, 506-517. doi: 10.1111/j.1365-3040.2008.01781.x

Jagadish, K. S. V., Cairns, J. E., Kumar, A., Somayanda, I. M., and Craufurd, P. Q. (2011). Does susceptibility to heat stress confound screening for drought tolerance in rice? Funct. Plant Biol. 38, 261-269. doi: 10.1071/FP10224

Jensen, C. R., Mogensen, V. O., Mortensen, G., Fieldsend, J. K., Milford, G. F. J., Andersen, M. N., et al. (1996). Seed glucosinolate, oil and protein contents of field-grown rape (Brassica napus L.) affected by soil drying and evaporative demand. Field Crops Res. 47, 93-105. doi: 10.1016/0378-4290(96)00026-3 
Jiang, Y., Lahlali, R., Karunakaran, C., Kumar, S., Davis, A. R., and Bueckert, R. A. (2015). Seed set, pollen morphology and pollen surface composition response to heat stress in field pea. Plant Cell Environ. 38, 2387-2397. doi: 10.1111/pce.12589

Kharin, V. V., Zwiers, F. W., Zhang, X., and Hegerl, G. C. (2007). Changes in temperature and precipitation extremes in the IPCC ensemble of global coupled model simulations. J. Clim. 20, 1419-1444. doi: 10.1175/JCLI4066.1

Killi, D., and Haworth, M. (2017). Diffusive and metabolic constraints to photosynthesis in Quinoa during drought and salt stress. Plants 6:49. doi: $10.3390 /$ plants 6040049

Kotak, S., Larkindale, J., Lee, U., Von Koskull-Döring, P., Vierling, E., and Scharf, K.-D. (2007). Complexity of the heat stress response in plants. Curr. Opin. Plant Biol. 10, 310-316. doi: 10.1016/j.pbi.2007.04.011

Lesk, C., Rowhani, P., and Ramankutty, N. (2016). Influence of extreme weather disasters on global crop production. Nature 529:84. doi: 10.1038/nature16467

Li, Y., Ye, W., Wang, M., and Yan, X. (2009). Climate change and drought, a risk assessment of crop-yield impacts. Clim. Res. 39, 31-46. doi: 10.3354/cr00797

Lohaus, G., and Moellers, C. (2000). Phloem transport of amino acids in two Brassica napus L. genotypes and one B. carinata genotype in relation to their seed protein content. Planta 211, 833-840. doi: 10.1007/s004250000349

Mahrookashani, A., Siebert, S., Hüging, H., and Ewert, F. (2017). Independent and combined effects of high temperature and drought stress around anthesis on wheat. J. Agron. Crop Sci. 203, 453-463. doi: 10.1111/jac.12218

Martínez-Rivas, J. M., Sánchez-García, A., Sicardo, M. D., García-Díaz, M. T., and Mancha, M. (2003). Oxygen-independent temperature regulation of the microsomal oleate desaturase (FAD2) activity in developing sunflower (Helianthus annuus) seeds. Physiol. Plant. 117, 179-185. doi: 10.1034/j.1399-3054.2003.00039.x

McDowell, N. G., Beerling, D. J., Breshears, D. D., Fisher, R. A., Raffa, K. F., and Stitt, M. (2011). The interdependence of mechanisms underlying climate-driven vegetation mortality. Trends Ecol. Evol. 26, 523-532. doi: $10.1016 /$ j.tree.2011.06.003

Menard, G. N., Moreno, J. M., Bryant, F. M., Munoz-Azcarate, O., Kelly, A. A., Hassani-Pak, K., et al. (2017). Genome wide analysis of fatty acid desaturation and its response to temperature. Plant Physiol. 173, 1594-1605. doi: $10.1104 /$ pp. 16.01907

Milla-Moreno, E. A., McKown, A. D., Guy, R. D., and Soolanayakanahally, R. Y. (2016). Leaf mass area predicts palisade structural properties linked to mesophyll conductance in balsam poplar (Populus balsamifera L.). Botany 94, 225-239. doi: 10.1139/cjb-2015-0219

Momayyezi, M., and Guy, R. D. (2017). Substantial role for carbonic anhydrase in latitudinal variation in mesophyll conductance of Populus trichocarpa Torr. \& Gray. Plant Cell Environ. 40, 138-149. doi: 10.1111/pce.12851

Momayyezi, M., and Guy, R. D. (2018). Concomitant effects of mercuric chloride on mesophyll conductance and carbonic anhydrase activity in Populus trichocarpa Torr. \& Gray. Trees Struct. Funct. 32, 301-309. doi: 10.1007/s00468-017-1632-5

Morrison, M. J., and Stewart, D. W. (2002). Heat stress during flowering in summer Brassica ECORC contribution no. 02-41. Crop Sci. 42, 797-803. doi: $10.2135 /$ cropsci2002.0797

Nankishore, A., and Farrell, A. D. (2016). The response of contrasting tomato genotypes to combined heat and drought stress. J. Plant Physiol. 202, 75-82. doi: 10.1016/j.jplph.2016.07.006

Ohsumi, A., Hamasaki, A., Nakagawa, H., Homma, K., Horie, T., and Shiraiwa, T. (2008). Response of leaf photosynthesis to vapor pressure difference in rice (Oryza sativa L.) varieties in relation to stomatal and leaf internal conductance. Plant Prod. Sci. 11, 184-191. doi: 10.1626/pps.11.184

Olsovska, K., Kovar, M., Brestic, M., Zivcak, M., Slamka, P., and Shao, H. B. (2016). Genotypically identifying wheat mesophyll conductance regulation under progressive drought stress. Front. Plant Sci. 7:1111. doi: $10.3389 /$ fpls.2016.01111

Pachauri, R. K., Allen, M. R., Barros, V. R., Broome, J., Cramer, W., Christ, R., et al. (2014). Climate Change 2014: Synthesis Report. Contribution of Working Groups, I, II and III to the fifth assessment report of the Intergovernmental Panel on Climate Change. IPCC.

Pantin, F., Monnet, F., Jannaud, D., Costa, J. M., Renaud, J., Muller, B., et al. (2013). The dual effect of abscisic acid on stomata. New Phytol. 197, 65-72. doi: $10.1111 /$ nph. 12013
Peet, M. M., Sato, S., and Gardner, R. G. (1998). Comparing heat stress effects on male-fertile and male-sterile tomatoes. Plant Cell Environ. 21, 225-231. doi: 10.1046/j.1365-3040.1998.00281.x

Piggott, J. J., Townsend, C. R., and Matthaei, C. D. (2015). Reconceptualizing synergism and antagonism among multiple stressors. Ecol. Evol. 5, 1538-1547. doi: $10.1002 /$ ece3.1465

Porterfield, D. M., Kuang, A., Smith, P. J. S., Crispi, M. L., and Musgrave, M. E. (2000). Oxygen-depleted zones inside reproductive structures of Brassicaceae: implications for oxygen control of seed development. Can. J. Bot. 77, 1439-1446. doi: 10.1139/b99-098

Prasad, P. V., Bheemanahalli, R., and Jagadish, S. K. (2017). Field crops and the fear of heat stress - opportunities, challenges and future directions. Field Crops Res. 200, 114-121. doi: 10.1016/j.fcr.2016.09.024

Prasad, P. V. V., Staggenborg, S. A., and Ristic, Z. (2008). "Impacts of Drought and/or Heat Stress on Physiological, Developmental, Growth, and Yield Processes of Crop Plants," in Response of Crops to Limited Water: Understanding and Modeling Water Stress Effects on Plant Growth Processes, Advances in Agricultural Systems Model. 1, eds L. R. Ahuja, V. R. Reddy, S. A. Saseendran, and Q. Yu (Madison, WI: ASA, CSSA, SSSA), 301-355. doi: 10.2134/advagricsystmodell.c11

Pritchard, F. M., Eagles, H. A., Norton, R. M., Salisbury, P. A., and Nicolas, M. (2000). Environmental effects on seed composition of Victorian canola. Aust. J. Exp. Agric. 40, 679-685. doi: 10.1071/E.A.99146

R Core Team (2015). R: A Language and Environment for Statistical Computing. Vienna: R Foundation for Statistical Computing. Available online at: http:// www.R-project.org/

Rathke, G.-W., Behrens, T., and Diepenbrock, W. (2006). Integrated nitrogen management strategies to improve seed yield, oil content and nitrogen efficiency of winter oilseed rape (Brassica napus L.): a review. Agric. Ecosyst. Environ. 117, 80-108. doi: 10.1016/j.agee.2006.04.006

Rieu, I., Twell, D., and Firon, N. (2017). Pollen development at high temperature: from acclimation to collapse. Plant Physiol. 173, 1967-1976. doi: $10.1104 /$ pp. 16.01644

Rolletschek, H., Borisjuk, L., Sánchez-García, A., Gotor, C., Romero, L. C., Martínez-Rivas, J. M., et al. (2007). Temperature-dependent endogenous oxygen concentration regulates microsomal oleate desaturase in developing sunflower seeds. J. Exp. Bot. 58, 3171-3181. doi: 10.1093/jxb/ erm154

Rossato, L., Lainé, P., and Ourry, A. (2001). Nitrogen storage and remobilization in Brassica napus L. during the growth cycle: nitrogen fluxes within the plant and changes in soluble protein patterns. J. Exp. Bot. 52, 1655-1663. doi: 10.1093/jexbot/52.361.1655

Sadras, V., Reynolds, M., De La Vega, A., Petrie, P., and Robinson, R. (2009). Phenotypic plasticity of yield and phenology in wheat, sunflower and grapevine. Field Crops Res. 110, 242-250. doi: 10.1016/j.fcr.2008.09.004

Saini, H., and Aspinall, D. (1982). Abnormal sporogenesis in wheat (Triticum aestivum L.) induced by short periods of high temperature. Ann. Bot. 49, 835-846. doi: 10.1093/oxfordjournals.aob. a086310

Saini, H., Sedgley, M., and Aspinall, D. (1983). Effect of heat stress during floral development on pollen tube growth and ovary anatomy in wheat (Triticum aestivum L.). Funct. Plant Biol. 10, 137-144.

Sehgal, A., Sita, K., Kumar, J., Kumar, S., Singh, S., Siddique, K. H., et al. (2017). Effects of drought, heat and their interaction on the growth, yield and photosynthetic function of lentil (Lens culinaris Medikus) genotypes varying in heat and drought sensitivity. Front. Plant Sci. 8:1776. doi: $10.3389 /$ fpls.2017.01776

Si, P., Mailer, R. J., Galwey, N., and Turner, D. W. (2003). Influence of genotype and environment on oil and protein concentrations of canola (Brassica napus L.) grown across southern Australia. Aust. J. Agric. Res. 54, 397-407. doi: 10.1071/AR01203

Sinaki, J. (2009). Study of physiological traits and analysis of the growth in canola (Brassica napus L.) under water deficit conditions. Am.-Eurasian J. Agric. Environ. Sci. 5, 226-235.

Singh, M., Kumar, J., Singh, S., Singh, V. P., and Prasad, S. M. (2015). Roles of osmoprotectants in improving salinity and drought tolerance in plants: a review. Rev. Environ. Sci. Biotechnol. 14, 407-426. doi: 10.1007/s11157-015-9372-8 
Stone, P., and Nicolas, M. (1994). Wheat cultivars vary widely in their responses of grain yield and quality to short periods of post-anthesis heat stress. Funct. Plant Biol. 21, 887-900. doi: 10.1071/PP9940887

Swap, R. J., Aranibar, J. N., Dowty, P. R., Gilhooly, W. P., and Macko, S. A. (2004). Natural abundance of ${ }^{13} \mathrm{C}$ and ${ }^{15} \mathrm{~N}$ in $\mathrm{C}_{3}$ and $\mathrm{C}_{4}$ vegetation of southern Africa: patterns and implications. Glob. Chang. Biol. 10, 350-358. doi: 10.1111/j.1365-2486.2003.00702.x

Théroux-Rancourt, G., Éthier, G., and Pepin, S. (2015). Greater efficiency of water use in poplar clones having a delayed response of mesophyll conductance to drought. Tree Physiol. 35, 172-184. doi: 10.1093/treephys/tpv006

Thies, W. (1971). Schnelle und einfache Analysen der Fettsäurezusammensetzung in einzelnen Rapskotyledonen. I. Gaschromatographische und papierchromatographische Methode. Z. Pflanzenzüchtung. 65, 181-202.

Ur Rahman, H., Malik, S. A., and Saleem, M. (2004). Heat tolerance of upland cotton during the fruiting stage evaluated using cellular membrane thermostability. Field Crops Res. 85, 149-158. doi: 10.1016/S0378-4290(03)00159-X

Vigeolas, H., Van Dongen, J. T., Waldeck, P., Huhn, D., and Geigenberger, P. (2003). Lipid storage metabolism is limited by the prevailing low oxygen concentrations within developing seeds of oilseed rape. Plant Physiol. 133, 2048-2060. doi: 10.1104/pp.103.031963

von Caemmerer, S., and Evans, J. R. (2015). Temperature responses of mesophyll conductance differ greatly between species. Plant Cell Environ. 38, 629-637. doi: $10.1111 /$ pce. 12449

Wahid, A., Gelani, S., Ashraf, M., and Foolad, M. R. (2007). Heat tolerance in plants: an overview. Environ. Exp. Bot. 61, 199-223. doi: 10.1016/j.envexpbot.2007.05.011

Wang, Y., and Frei, M. (2011). Stressed food - the impact of abiotic environmental stresses on crop quality. Agric. Ecosyst. Environ. 141, 271-286. doi: 10.1016/j.agee.2011.03.017

Warren, C. (2008). Soil water deficits decrease the internal conductance to $\mathrm{CO}_{2}$ transfer but atmospheric water deficits do not. J. Exp. Bot. 59, 327-334. doi: $10.1093 /$ jxb/erm314

Wilkinson, S., and Davies, W. J. (2010). Drought, ozone, ABA and ethylene: new insights from cell to plant to community. Plant Cell Environ. 33, 510-525. doi: 10.1111/j.1365-3040.2009.02052.x

Yan, D., Easwaran, V., Chau, V., Okamoto, M., Ierullo, M., Kimura, M., et al. (2016). NIN-like protein 8 is a master regulator of nitrate-promoted seed germination in Arabidopsis. Nat. Commun. 7:13179. doi: $10.1038 /$ ncomms13179

Yan, W., Zhong, Y., and Shangguan, Z. (2016). A meta-analysis of leaf gas exchange and water status responses to drought. Sci. Rep. 6:20917. doi: 10.1038/srep20917

Yousfi, S., Serret, M. D., Márquez, A. J., Voltas, J., and Araus, J. L. (2012). Combined use of $\delta^{13} \mathrm{C}, \delta^{18} \mathrm{O}$ and $\delta^{15} \mathrm{~N}$ tracks nitrogen metabolism and genotypic adaptation of durum wheat to salinity and water deficit. New Phytol. 194, 230-244. doi: 10.1111/j.1469-8137.2011.04036.x

Yuan, W., Cai, W., Chen, Y., Liu, S., Dong, W., Zhang, H., et al. (2016). Severe summer heatwave and drought strongly reduced carbon uptake in Southern China. Sci. Rep. 6:18813. doi: 10.1038/srep 18813

Zarei, G., Shamsi, H., and Dehghani, S. M. (2010). The effect of drought stress on yield, yield components and seed oil content of three autumnal rapeseed cultivars (Brassica napus L.). J. Res. Agric. Sci. 6, 29-37.

Zhang, X., Lu, G., Long, W., Zou, X., Li, F., and Nishio, T. (2014). Recent progress in drought and salt tolerance studies in Brassica crops. Breed. Sci. 64, 60-73. doi: $10.1270 /$ jsbbs. 64.60

Zhao, C., Liu, B., Piao, S., Wang, X., Lobell, D. B., Huang, Y., et al. (2017). Temperature increase reduces global yields of major crops in four independent estimates. Proc. Natl. Acad. Sci. U.S.A. 114, 9326-9331. doi: $10.1073 /$ pnas.1701762114

Zscheischler, J., Mahecha, M. D., Von Buttlar, J., Harmeling, S., Jung, M., Rammig, A., et al. (2014). A few extreme events dominate global interannual variability in gross primary production. Environ. Res. Lett. 9:035001. doi: $10.1088 / 1748-9326 / 9 / 3 / 035001$

Conflict of Interest Statement: The authors declare that the research was conducted in the absence of any commercial or financial relationships that could be construed as a potential conflict of interest.

Copyright (c) 2018 Elferjani and Soolanayakanahally. This is an open-access article distributed under the terms of the Creative Commons Attribution License (CC BY). The use, distribution or reproduction in other forums is permitted, provided the original author(s) and the copyright owner(s) are credited and that the original publication in this journal is cited, in accordance with accepted academic practice. No use, distribution or reproduction is permitted which does not comply with these terms. 